\title{
ECONOMICS
}

\section{HOW MUCH ARE RESOURCE PROJECTS WORTH? A CAPITAL MARKET PERSPECTIVE}

by

\author{
Liang Li
}

Business School University of Western Australia

\section{DISCUSSION PAPER 12.13}




\title{
HOW MUCH ARE RESOURCE PROJECTS WORTH? A CAPITAL MARKET PERSPECTIVE
}

\author{
by \\ Liang $\mathrm{Li}^{*}$ \\ Business School \\ The University of Western Australia
}

\begin{abstract}
$\underline{\text { Abstract }}$
In many cases, a company's capital investment decision is not a one-off "yes/no", but occurs as a result of a sequence of decisions of a more preliminary nature. Major resource investment projects, for example, typically have to pass several "feasibility" tests before companies fully commit to them. Accordingly, there is an "investment pipeline" of projects. In this study, we examine the stock-market reaction to announcements of the progress of investment projects as they flow down the pipeline. Using a sample of Australian stocks in the resources sector, we find substantial positive abnormal returns when firms announce a change in the status of their planned projects. Interestingly, the magnitude of reaction varies substantially with the location of the project in the pipeline (such as the project being "committed", "under construction" and "completed"). These results reveal the value-enhancing effects of the market being informed of projects in the later stages of the investment pipeline. Further analysis shows that larger stock-market reactions tend to be associated with bigger projects, smaller firms and those with lower free cash flow.

JEL classification: G14 G31
\end{abstract}

Keywords: Capital expenditure; Resource project; Event study

\footnotetext{
* I would like to acknowledge the assistance of my supervisor, Kenneth W Clements, the financial support of a BHP Billiton scholarship and thank Steve Smith of Deloitte Access Economics for generously providing data to the University of Western Australia. I also thank the helpful comments from Grace Gao. The views expressed herein are my own and not necessarily those of BHP Billiton.
} 


\section{Introduction}

The recent rise of the Australian resources sector has attracted much attention from the financial sector, macroeconomists and the media. Undoubtedly, the boom in this sector has enhanced mining-company profitability, lead to substantial investment in new projects and kept the Australian economy more buoyant than would otherwise be the case. The benefits of the boom are widely distributed throughout the economy by several mechanisms. First, there is the direct and indirect stimulus to activities in the resources sector and supplying industries. Second, higher royalties, taxes and charges paid by the sector, their employees and shareholders enable government to provide more public services and (possibly) keep other taxes from rising. Third, the Australian dollar has appreciated, which increases real incomes by lowering the cost of imports. On the other hand, the boom also has negative effects on other exporters and firms in the import-competing sector due to Gregory (1976) effects or the "Dutch disease". These are the most widely cited ways in which the boom works its way through the economy. ${ }^{1}$ A less widely appreciated mechanism is the wealth effect coming from the higher prices of mining companies' shares. An objective of this research is to explore the magnitude of the price impact associated with the development of resource projects using a sample of more than 300 resource project announcements made by Australian firms over the last ten years.

Compared with most other types of capital investments, resource projects have a unique feature, viz., their staged and sequential nature. Resource projects usually have to pass through several "feasibility" tests before companies fully commit to them. Accordingly, projects flow down an "investment pipeline" that comprises several distinct parts: Projects are located in the pipeline by being described as being "possible", "under consideration", "committed", "under construction", "completed" or "deleted". These stages are well understood by the sector of financial markets; and importantly this information about the status of projects is usually made public by resource companies. We use the rich data contained in the Investment Monitor, published by Deloitte Access Economics, to conduct an event study to investigate the stock market reaction to announcements that projects have moved down the pipeline. Accordingly, a second objective of this research is to study the workings of the investment pipeline and the value investors place on early announcements of projects.

\footnotetext{
${ }^{1}$ Resource booms are an important reoccurring feature of the Australian economy. For an assessment of the most recent boom on the marcoeconomy, see Battellino (2010).
} 
Previous research has established that the stock market reacts strongly and spontaneously to announcements of significant capital investment decisions, a finding consistent with capital market efficiency. ${ }^{2}$ However, prior research on this issue is built on the premise that capital investments are "one-off" events. By contrast, we emphasise that capital investments involve a series of decisions and, potentially, every major step in the project planning process can impact on the company's share price. This is consistent with the seminal paper by Pindyck (1991) who posits that rather than being discrete decisions, investments in fact take place in stages that must be carried out in sequence, so that every stage in the evolution of projects plays a role in determining the future cash flow. To the extent that a firm's stock price is an aggregate indicator of its expected future cash flow, it follows that stock price may respond not only to the final investment decision, but also to preliminary developments that take place prior to the final one. Consistent with this prediction, we document substantial market reaction around the announcements of resource project developments. Importantly, we find different market reactions for projects in different stages of the pipeline, which reveals the value of this information.

Having established the market reaction, we then analyse the underlying economic factors that drive this result. At least two sources emerge from the literature that may explain why project announcements can translate into stock prices. First, there is the investment opportunities idea of Chung et al. (1998), Burton et al. (1999) and Del Brio et al. (2003), among others, whereby market reactions are stronger for firms with high-quality investment opportunities. The reason is that these firms are more likely to undertake positive net present value (NPV) projects. Second, Jensen (1986) proposes that excessive free cash flow may provide incentives for managers to undertake negative NPV projects, while the use of external financing strengthens market monitoring for managers and thereby leads to positive NPV projects. Consequently, market reaction is expected to be stronger for firms with less free cash flow. However, empirical evidence in this perspective is still inconclusive with supporting results for the US (Vogt, 1997) and the Spain (Del Brio et al., 2003), but

\footnotetext{
${ }^{2}$ Starting from McConnell and Muscarella (1985), the literature has shown the substantial linkages between capital expenditure announcements and the reaction of stock prices. In this work, stock prices are found to react positively to an increase in unexpected capital expenditures. Subsequent studies such as Statman and Sepe (1989) and Alli et al. (1991) show that announcements that individual projects have been terminated contribute to stock prices in the United States. More recent studies such as Blose and Shieh (1997), Chung et al. (1998) and Del Brio et al. (2003) attempt to uncover the causes of differential market reactions to announcements of a similar nature.
} 
insignificant results for Singapore (Chen et al., 1997, 2000). We find evidence in support of the free cash flow theory, but not the investment opportunities hypothesis.

The remainder of the paper is organized as follows. Section 2 describes the basic source of the data, the Investment Monitor, published by Deloitte Access Economics, and elaborates the research methodology. Section 3 investigates the stock market reactions, and Section 4 analyses the determinants of abnormal returns in terms of the characteristics of the firms and projects. Section 5 concludes.

\section{Data and Methodology}

The main objective of this paper is to use the stock market to analyse the value of resource projects. We do this by investigating the stock-price reaction around the time at which project announcements are made. We construct a sample consisting of announcements regarding the progress of resource projects of companies listed on the Australian Securities Exchange (ASX) over the period 2001 to 2010. This section describes these matters.

\section{The Investment Monitor}

A rich source of information on recent Australian investment projects is provided by the Investment Monitor (hereafter, $\underline{\mathrm{IM}}$ ), a quarterly publication produced by the economic consultancy firm, Deloitte Access Economics. This publication lists all Australian investment projects costing more than \$A20m and covers private and public non-residential building, civil and engineering construction, and equipment investment projects in all industries. The emphasis is on discrete projects where capital expenditure is confined to a single location or purpose, rather than a large number of separate small scale capital investment. Each project in the $\underline{\mathrm{IM}}$ is assigned a unique record number so that it can be tracked over future editions of the publication. The recorded information is the firm to which the project belongs, the capital expenditure of the project, a brief statement of the project (e.g. "Gold and Copper mine, Prominent Hill"), date started, date completed, the industry classification and the number of individuals employed in the construction and operation phases of the project. Importantly, also recorded is the status of each project, defined as: (1) possible, (2) under consideration, (3) committed, (4) under construction, (5) completed, and (6) deleted. Table 1 provides more detailed 
definitions of these project "states". During its lifecycle, a project typically moves from one state to another in the $\underline{\mathrm{IM}}$ and we track these changes. ${ }^{3}$

In this paper, we focus on resource investment projects in the mining and energy industries. The undertaking of a resource project consists of several preliminary steps, which can be thought of as an investment "pipeline". It could start with either the discovery of an ore body or the acquisition of a project, and then lead onto an early planning stage, or what is known as a "scoping study". Then, several feasibility studies are conducted to obtain the approval from the board of the company and relevant government departments. The necessary funding for the project is then secured. Only after that stage does construction take place and the project becomes operational. In contrast to other types of investment projects, resource projects occur in distinct stages that must be carried out sequentially, and the financing of these projects tends to rely on equity rather than debt. Thus, resource projects would seem to provide a good opportunity to measure the stock market reaction to announcements of changes in their status.

\section{An Event}

ASX Listing Rules require that once a company becomes aware of any information that a reasonable person would expect to have a material effect on the price or value of the company's securities, it must immediately inform the ASX. These ASX announcements would be one way that the IM updates their database. ${ }^{4}$

In this paper, we track the evolution of resource projects that are developed by publicly listed companies. We regard the announcement that a project has moved into a new state as "an event" and examine the stock market reaction around this time.

\section{Data Collection Procedures}

As mentioned above, the data used in this study refer to ASX listed firms that have resource projects included in the $\underline{I M}$ between 2001 and 2010. The project announcements are obtained from SIRCA's ASX company announcement (Signal G) database. We employ the following procedures to search for these announcements:

\footnotetext{
${ }^{3}$ A project can skip some states, such as jumping to the committed state from the possible state. A project can fail any time, which is recorded as moving to the deleted state.

${ }^{4}$ ASX rules apply only to publicly listed companies. For the other companies, the IM would use other sources. The IM states that "it also collects information from a variety of media, government and private sources. Some of the information is from lists complied by others. Where possible, it checks major projects with the relevant company. "(Investment Monitor, September 2010)
} 
- Identify the search period: Using the IM, we identify the quarter in which the project enters into a new state as the searching period. To allow for lags in the updating of the $\underline{\mathrm{IM}}$, we expand the searching period from one quarter to three quarters, the current and preceding two quarters.

- Search for the announcements: As mentioned above, IM records the firm name, the project name, the location and the product. We use this project name as a keyword to search for the relevant announcement in the Signal G database. This search is carried out for the current quarter and the preceding two quarters.

- Missing observations: If we cannot find the relevant announcement by using the above steps, we regard this as a missing observation.

\section{Data Description}

To give a feel for the nature of the projects, Table 2 contains some representative examples of how the $\underline{\mathrm{IM}}$ tracks projects. For example, row 1 presents the whole lifecycle of project number 8048, an iron-ore project undertaken by BHPB. This project first enters the IM in 2005:4 in the consideration state, in 2006:2 it skips the committed state and jumps to the construction state, and finally it is completed in 2008:3. The estimated cost of this project was $\$ 1,700 \mathrm{~m}$ at the start and this escalated to $\$ 2,050 \mathrm{~m}$ by the end. Sometimes, projects move from one state to another one sequentially as is illustrated by the gold project in row 4 . The cost escalates over the life of this project (from $\$ 700 \mathrm{~m}$ to $\$ 1,800 \mathrm{~m}$ ) also. However, this is not always the case, as can be seen from the history of the electricity project in row 2 .

Table 3 reports that in the $\underline{\mathrm{IM}}$ database from 2001 to 2010,442 resource projects of listed firms are recorded and the status of these projects changes 825 times. Our sample covers 220 projects, containing 301 announcements of status changes. Thus, we deal with about $50 \%$ of the projects and $36 \%$ of the events. Table 4 presents the number and cost of projects by industry. As can be seen, oil and gas projects have the highest average cost at more than $\$ 1 \mathrm{~b}$; then come iron ore projects at $\$ 956 \mathrm{~m}$. Iron ore, gold and oil and gas projects account for approximate $50 \%(75 \%)$ of the total number (cost).

Table 5 reports the immediate "history" of events by giving their distribution by "origin" and "destination". For example, the entry in the first row and second column, 45, means that 45 new projects first enter the $\underline{\mathrm{IM}}$ in the possible state. As can be seen, most projects enter the $\underline{\mathrm{IM}}$ in the consideration state and others are concentrated in the 
possible and committed states. Each of the largest entries in rows 2-5 are on the main diagonal, which means the most common event is a one-step progression of projects down the investment pipeline.

Table 6 shows descriptive statistics of the sample. Each firm owns, on average, 1.6 projects and makes 2.2 announcements, which means each project is associated with about 1.4 announcements. The maximum number of announcements by any one firm (project) is 20 (4). From Figure 1, it can be seen that while the mean project cost is $\$ 575 \mathrm{~m}$, there are many that cost less than $\$ 100 \mathrm{~m}$. Projects costing more than $\$ 1 \mathrm{~b}$ usually relate to oil and gas or iron ore developments. Figure 2 shows that the distribution of market capitalisation is not dissimilar to that of project cost, which points to the importance of single-project firms. To further explore this, Figure 3 gives the distribution of the project-cost-to-firm-size ratio. There is substantial dispersion, with spikes at 0.5 and 5+. But if we use the median as a measure of central tendency, on average projects cost about $30 \%$ of capitalisation.

\section{The Value of Information}

When a company announces that it is going to undertake a substantial project, it could be reasonable to suppose investors reappraise the company's prospects and revise (upward or downward) their expectations of the future profitability. The change in the company's stock price then measures the value of this reappraisal. We use the event study methodology to isolate that part of the price change attributable to the announcement of the project.

The methodology involves the following elements:

- Expected returns: We estimate a one-factor market model regression of the following form

$$
R_{i t}=\alpha_{i}+\beta_{i} R_{m t}+\varepsilon_{i t} .
$$

In this equation, $R_{i t}$ is the return on company $i$ 's stock on day $t, R_{m t}$ is the return on the relevant market index (the ASX Resource 100 index, from SIRCA), $\alpha_{i}$ and $\beta_{i}$ are parameters and $\varepsilon_{i t}$ is a disturbance term. This model provides the expected return $E\left(R_{i t}\right)=\alpha_{i}+\beta_{i} R_{m t}$. We use to estimate equation (1) a 110-day window that starts 120 days before the event (day 0 ) and ends 10 days before, which we write as $[-120,-10]$.

- Abnormal returns: If market model is correctly specified, the disturbance term of model (1) captures new information about the company that hits the market. 
Therefore, the impact of new information is the abnormal return, the difference between actual and expected returns, which can be estimated as $R_{i t}-\left(\hat{\alpha}_{i}+\hat{\beta}_{i} R_{m t}\right)$, where the hats denote estimates.

- Event windows: We use as the maximum event window 21 days, written [-10, +10 ]. We further split this into several small intervals, such as a pre-event window, $[-10,-1]$, post-event window, $[+1,+10]$ and 3-day event window, $[-1,+1]$. These windows are used to calculate the cumulative abnormal return, $\sum_{t=\tau_{1}}^{\tau_{2}} R_{i t}-\left(\hat{\alpha}_{i}+\hat{\beta}_{i} R_{m t}\right)$, where $\tau_{1}$ and $\tau_{2}$ define the event window. As the abnormal return measures the intensity of the market reaction to the announcement, it reflects the additional value created by the changed status of the project.

\section{The Abnormal Returns}

This section analyses the patterns of the abnormal returns associated with changes in the status of the projects.

\section{Daily Abnormal Returns}

In Panel A of Table 7, we report information on the daily abnormal returns surrounding the announcement day. These returns are averaged over events. We start by examining the stock-market response for all 301 events and column 2 of this table contains the results. The sixth element of this column is the average abnormal return on the announcement day, which is $1.66 \%$ and significant at the $1 \%$ level. Furthermore, the median announcement day abnormal return is $1.05 \%$ and $65 \%$ of the announcement effects are positive, indicating that returns are not driven by outlier observations. Thus, shareholders of our sample firms experience significant wealth gains from announcements of projects moving down the investment pipeline. The elements above and below the sixth element in column 2 indicate that there are no significant abnormal returns preceding or following the announcement day. The only exception to this rule is the fourth day after the announcement. Thus, on average, there is no substantial information "leakage" before announcements and no subsequent substantial price "reversal" after announcements.

Panel F of Figure 4 is a plot of the time profile of the daily abnormal returns for all projects. That is, it is a plot of the elements of Panel A of column 2 of Table 7. As can be seen, the abnormal returns spike on the announcement day. Our finding of 
significantly positive abnormal returns on the event day is broadly consistent with previous findings; but the magnitude of our finding $(1.66 \%)$ is greater than that found in related previous research. For example, Chan et al. (1995) report that the average 2day abnormal return associated with business expansions from 85 observations is $0.69 \%$, while Burton et al. (1999) find that the average 2-day abnormal return of nonimmediate cash-generating investments from 68 observations is $0.5 \%$. We suggest that two reasons lead to this difference. Firstly, in contrast to the prior literature that focuses more on the impact of discrete capital investment decisions, this study concentrates on the lifecycle of investment projects. We investigate the stock market reaction to announcements regarding not only the final investment decision ("committed"), but also the more preliminary decisions in the process ("possible", "under consideration"). In our sample, the mean 3-day abnormal return for the "committed" state, which means companies make the final investment decision, is $1.07 \%$. This result is very similar to that reported by Burton et al. (1999). Secondly, the strong demand of resource commodities over the decade under investigation lead to buoyant prices. The reaction to the announcements of new capital investments made by companies may be interpreted as a signal that informed opinion expects continued buoyancy of prices and higher future profits.

In order to further study price reaction, we partition the whole sample into five categories by project state, "possible", "consideration", “committed", “construction" and "completion". The box in panel A of Table 7 refers to the announcement day reactions by state. These results show that average abnormal returns on the announcement day are positive in all states, but different. We find statistically significant returns for the possible, consideration and completed states. These returns are $2.44 \%, 2.52 \%$ and $2.01 \%$, respectively. In contrast, the returns for the committed and construction states are not significant. The elements above and below the box indicate that there are no significant abnormal returns prior to or after the announcement day, except for the construction state the day before the announcement. The abnormal returns of committed and construction states on the event day are less than those on the preceding day, which could imply that some information leakage takes place here. Panels A-E of Figure 4 plot the returns for the five states.

\section{Cumulative Abnormal Returns}

We employ different event windows to calculate the cumulative abnormal returns so as to shed further light on the impact of the announcements. We again use 
the notation $[\mathrm{x}, \mathrm{y}]$ to denote the length of the window with $\mathrm{x}$ and $\mathrm{y}$ the number of days from the event. Days are measured relative to the event, so that $[-10,-1]$, for example, means that abnormal returns are computed over the period starting 10 days before the event and ending 1 day before the event. The time intervals selected are $[-10,-1],[+1$, $+10]$ and $[-10,+10]$, which represent the pre-event, post-event and entire event periods. Considering the possibility of information leakage and releasing after the trading hours, we also calculate 3-day cumulative abnormal returns to better capture the market reaction, that is $[-1,+1]$.

The first entry in column 2 of Panel B of Table 7 shows that for the all events the average 3-day cumulative abnormal return is $2.35 \%$, which is significant. Cumulative abnormal returns of pre-event and post-event are not significant. For the entire period $[-10,+10]$, the mean abnormal return is $1.29 \%$, which is not significant. However, the other columns of Panel B reveal that the average cumulative abnormal returns differ by project state as follows:

- Possible: The announcements of projects moving into the possible stage are associated with significant average 3-day cumulative abnormal return of $1.92 \%$, whilst over the post-event period $[+1,+10]$, the cumulative abnormal return is significantly negative. That is, at the initial stage of projects, even though investors react positively to these announcements on the event day, stock prices swiftly reverse after the announcements. Finally, the whole period cumulative abnormal return $[-10,+10]$ is close to zero.

- Consideration: The average 3-day cumulative abnormal return of the consideration state is $2.68 \%$ and significant, and the whole-period cumulative abnormal return is still positive $(2.38 \%)$. This finding is in contrast to the results for the possible state discussed above. According to Clements et al. (2011), a project in the consideration state has on average a higher probability of ultimately being completed than one in the possible state. The higher survival rate is likely to give investors greater confidence in the ultimate success of firms with a project classified as "under consideration". From financial theory, the value of a firm changes as the stock market receives general or firm-specific information that changes expectations about future cash flows. Thus, the substantial cumulative abnormal returns for firms with projects in the consideration state could reflect a perception of reduced risk. 
- Committed: In contrast to the possible and consideration states, when projects move into the committed state, the stock market does not have an apparent reaction around the announcement period. The pre-event period $[-10,-1]$, however, is associated with a significant positive cumulative abnormal return of $2.00 \%$, which indicates that somehow the information has already leaked before the disclosure of the announcement. This pre-event cumulative abnormal return is the largest one among the five states.

- Construction and completed: As firm value increases with a firmer expectation of higher future cash flow, the stock market should react more positively when investment opportunities become more certain. Consistent with this expectation, the 3-day cumulative returns around announcements that projects have moved to the construction and completed states are the highest (or equal highest) across all states. ${ }^{5}$

Figure 5 gives the distribution of the cumulative abnormal returns for all states. As can be seen, the distribution in Panels A and B seems to be not too far from symmetric, but in all for cases there is substantial dispersion. By multiplying the abnormal return by the corresponding firm's market capitalisation, we obtain the dollar value of wealth creation for shareholders. Figure 6 plots this wealth created in the 3-day event window. As can be seen from Panel A, more than 50\% of announcements generate wealth, and the total is approximately $\$ 23$ billion. Nearly one-half of this stems from projects that enter the construction phase (Panel E). Table 10 summarises wealth creation on the event day and over short and long run horizons. There are three noteworthy features: First, column 6 of Panels A and B shows that wealth created in the short term is substantially larger than that on the event day; presumably, the reason is that the 3-day event window tends to avoid issues of late announcements and information leakage. Second, Panels B and C show (again) that projects entering the construction phase create the most value. Third, over long term, most of the short-term value generated disappears except for the construction state.

\footnotetext{
${ }^{5}$ To examine the robustness of the findings, we investigate alternatives for the computation of abnormal returns. First, we employ market-adjusted returns, $R_{i t}-R_{m t}$. Table 8 reports the results which are broadly consistent with the findings in Table 7. Interestingly, in the pre-event and entire event window, most mean returns become significant, which implies possible information leakage and the substantial wealth creation. Second, we extend the estimation window from 110 trading days to 240 trading days, [-250,-10], to calculate the abnormal returns. The results are reported in Table 9. Compared with Table 7, the abnormal returns are now larger and more significant. It is to be noted that the post-event average cumulative abnormal return of the possible state is $-3.04 \%$, compared with $-2.75 \%$ in Table 7, which further confirms the existence of the price reversal for projects in this state.
} 


\section{Differences between States}

According to the results analysed above, the abnormal returns and cumulative abnormal returns of different states are distinct. However, are they statistically different and, if so, why? In this sub-section, we analyse this issue.

Panel C of Table 7 employs the information of Panels A and B to obtain the mean return differences across the five states. These differences are presented in the form of three skew-symmetric matrices. For example, Part (i) of the panel refers to event day returns and compares the mean returns associated with the state indicated by the row label and the state indicated by the column. Taking the entry $-0.08 \%$ in the possible row and consideration column, this is the difference between the event-day abnormal return for the possible state, $2.44 \%$, from the sixth entry of column 3 of Panel A of the table, and the corresponding entry for the consideration state $2.52 \%$, from column 4 of the same row. As this $-0.08 \%$ difference has a standard error of $1.34 \%$, it is not significantly less than zero, which means that the impact of announcements of project moving into the possible state is not significantly weaker than that of the consideration state. The other elements of Panel $\mathrm{C}$ are similarly interpreted and one-tailed t-tests can be used to test the hypothesis that these differences are greater or less than zero.

The key result for Part (i) of panel $\mathrm{C}$ is contained in the row for the committed state, row 3. As can be seen, all elements here are negative and significant except one. This means that announcing that a project enters into the committed state is less important than all others on the event day. Part (ii) shows that in broad outline, the above result carries over to the 3-day window. The differences between row 3 of Part (i) and Part (ii) are (a) the mean difference between the committed state and the possible state becomes insignificant and (b) the difference between the committed state and the construction state becomes significant. No elements of Part (iii), which refers to the 21-day window, are significant. Thus, over the longer term, no state is statistically different from any other.

The above results can be summarised as follows:

- Around the announcement day, the impact of announcements that projects enter into the consideration and completed states outweighs that of projects entering the committed state. We suggest that the possible information leakage of the committed state (which has the largest pre-event cumulative 
abnormal return among the five states) results in these significant differences.

- Over the longer term, there is no significant effect of different states on stock-price reactions.

\section{The Role of Firm and Project Characteristics}

To enhance the understanding of the market reaction around project announcements, in this section we analyse the impact of the characteristics of firms and projects by considering:

- The number of partners in the project. We differentiate projects operated as a joint venture and those that are not. A large body of research on capital investment suggests that the stock market reactions to joint venture projects are different to those for non-joint venture projects. ${ }^{6}$

- The industry. We consider the industry to which a project will belong when completed.

- Investment opportunities. Previous studies have documented that the stock market reaction to capital investment decisions depends largely on the market's assessment about the quality of the firm's investment opportunities. ${ }^{7}$ Following these studies, we shall use Tobin's q, defined as $q_{i t}=\left(E_{i t}+L_{i t}\right) / A_{i t}$, where for firm $i$ at the time $t, E_{i t}$ and $L_{i t}$ are the market value of equity and the book value of current liabilities, respectively, and $A_{i t}$ is the book value of total assets. ${ }^{8}$ We distinguish between firms with low and high q values.

- Free cash flow. According to Jensen (1986), free cash flow plays a critical role in explaining the market reaction to capital investment announcements. This theory states that firms with a high-free-cash-flow tend to finance nonvaluable investment projects rather than pay it out to shareholders, while firms with a low-free-cash-flow are more likely to seek new external financing for capital investment projects. Due to the corresponding monitoring brought about by the new external financing, the corporate

\footnotetext{
${ }^{6}$ For example, McConnell and Nantell (1985), Keown et al. (2005) and Burton et al. (1999).

${ }^{7}$ See Chung et al. (1998), Blose and Shieh (1997) and Chen et al. (2002).

${ }^{8}$ Denis (1994), Chung and Pruitt (1994), Chen et al. (2000) and Del Brio et al. (2003) show that $q_{i t}$ defined in this way explains more than $96 \%$ of the variability of Tobin's q. Our $q_{i t}$ is measured at the end of the fiscal year prior to the announcement.
} 
governance of these firms is likely to be more transparent, enhancing the firms' performance. Thus, firms with low (high)-free-cash-flow levels are more likely to experience positive (negative) market reactions after capital investment announcements. ${ }^{9}$ Following Lehn and Poulsen (1989), Lang and Litzenberger (1989), Szewcyzk et al. (1996) and Chen et al. (2009), we measure free cash flow as a proportion of assets $(F)$ and define high (low) cash flow firms as those with $F$ above (below) the median.

To implement the above ideas, we estimate the equation $C A R_{i}=\beta_{1}+\beta_{2} M_{i}+\beta_{3} J V_{i}+\beta_{4} Q_{i}+\beta_{5} F_{i}+\varepsilon_{i}$, where $C A R_{i}$ represents the cumulative abnormal return for announcement $i$, and $M_{i}, J V_{i}, Q_{i}$ and $F_{i}$ are dummy variables referring to the mining industry, a joint venture, a high value of Tobin's $q$ and a high free cash flow, respectively, while $\varepsilon_{i}$ is a disturbance term. The intercept $\beta_{1}$ measures expected returns for the base case when the four dummies are zero, that is, for the projects in the energy industry, not a JV, with a low q value and a low free cash flow.

Panel A of Table 11 reports the results around the announcement day when the event window is $[-1,+1]$. We start by excluding all firm and project characteristics and just include an intercept in the equation. The estimate of this intercept is given as the first element of column 1 of the table, $2.35 \%$. This is the mean return that was previously reported in Section 3. The second element in this column is the mean 3day cumulative abnormal return for energy projects, which is $1.51 \%$ and significant. The next element in the same row is the difference between the mean return for mining and that for the energy industry, $1.19 \%$. As this is significant greater than zero under a one-tailed t-test, we conclude that mining projects yield higher abnormal returns than do energy projects. Similarly, the returns for projects that are not JVs and whose owner has a low free cash flow are significantly higher than those not in this category. Tobin's q is not significant. Panels B and C of the table redo the analysis for before and after the event day. The only significant effect is for JV projects during the post-event period. In Panel D, we use the 21-day returns and find no significant impact of firm and project characteristics.

Next, to analyse the impact of firm and project size, we estimate $C A R_{i}=\lambda_{1}+\lambda_{2} \log C_{i}+\lambda_{3} \log M k t_{i}+\varepsilon_{i}$, where for announcement $i, \log C_{i}$ is the

\footnotetext{
${ }^{9}$ This hypothesis has been completely or partly verified by Vogt (1997) and Del Brio et al.(2003) using U.S. and Spanish data, while Chen et al. $(1997,2000)$ do not find significant effects with Singaporean data.
} 
logarithm of the project cost, $\log M k t_{i}$ is the logarithm of market capitalisation of the corresponding firm in the month before the announcement and $\varepsilon_{i}$ is a disturbance term. Using the 3-day cumulative abnormal returns, Table 12 contains the results. As can be seen, returns rise with project size and fall with firm size. Interestingly, as the coefficients of these two variables sum to approximately zero, an increase in project size accompanied by an equiproportional rise in the size of the firm leaves returns more or less unchanged. This implies that these two effects upset each other so that a ratio formulation is appropriate, as in the third equation of each panel of this table. The coefficient of this ratio is significant in three out of six cases and is of the order of one half; the exception is for announcements that projects have been completed, where the coefficient about 2 . Thus, in most cases the elasticity of the share price with respect to project cost is about 0.5 , while the firm size elasticity is $-0.5 .^{10}$

The results of this section can be summarised as follows: First, some firm/project characteristics are important determinants of the stock market reaction. Announcements of mining projects, as opposed to energy, tend to generate higher returns, while those pertaining to projects that are joint ventures and firms with high free cash flow are lower. Second, the market reaction also increases with project size and decreases with firm size. Relative project size (that is, the ratio of project size/firm size) drives excess returns with an elasticity of about 0.5 .

\section{Summary and Conclusion}

Many large investment projects pass a number of preliminary tests before obtaining the final go-ahead decision by the company. But information on these preliminary tests is usually internal to the company and not made public. By contrast, resource companies (mining and energy) release this information with their projects classified as "possible", "under consideration", "committed", "under construction", "completed" or "deleted". As projects move from one stage to another, they can be thought of as flowing down the "investment pipeline".

Using information from Deloitte Access Economics' Investment Monitor to identify more than 300 announcements by Australian resource companies on changes in the location of their projects in the investment pipeline, we studied the value imputed to the release of this information by the capital market. We found substantial market reactions with abnormal returns that are both statistically and economically

\footnotetext{
${ }^{10} \mathrm{We}$ also added dummy variables for each state and found that the results of Table 10 are mainly unaffected.
} 
significant. For example, the average 3-day cumulative abnormal return is $2.35 \%$. This translates into approximately $\$ 23 \mathrm{~b}$ of wealth created for shareholders, which is about $20 \%$ of the cost of the projects. The market seems to discount announcements that projects are in the early stages of the pipeline (the "possible" and "under consideration" stages); later stages are more valuable. We also analysed the underlying economic factors that drive market responses to the announcements. The number of partners in the project (whether or not it is a joint venture), its industry (mining versus energy), and the free cash flow of the firm involved were found to be significant determinants. Additionally, higher returns were associated with a smaller firm size and larger project size.

This research is ongoing and there are several possible extensions including:

- Some companies have multiple projects, while some projects involve multiple announcements. Are there any fixed effects that capture the idea that some companies are better project managers than others, for example?

- When moving down the investment pipeline, some projects skip states. Are there any special characteristics of these projects?

- Some projects experience large cost escalations over their lives. What role does this play on returns?

- How does the market react to projects that are deleted from the Investment Monitor's list? Relatedly, do these projects fail for all time, or just get "shelved" to be resurrected when the next boom comes around?

\section{References}

Alli, K.L., G.G. Ramirez and K. Yung (1991), “Corporate Headquarters Relocation: Evidence from the Capital Markets", Real Estate Economics, 19: 583-600.

Battellino R. (2010), "Mining Booms and the Australian Economy", Reserve Bank of Australia Bulletin, March 63-69.

Blose, L.E. and J.C.P. Shieh (1997), "Tobin's q-Ratio and Market Reaction to Capital Investment Announcements”, Financial Review, 32: 449-476.

Burton M.B., A.A. Lonie and D.M. Power (1999), "The Stock Market Reaction to Investment Announcements: The Case of Individual Capital Expenditure Projects", Journal of Business Finance and Accounting, 26: 681-708.

Chan, S.H., G.W. Gau and K. Wang (1995), "Stock Market Reaction to Capital Investment Decisions: Evidence from Business Reallocations", Journal of Financial Quantitative Analysis, 30: 81-100.

Chen, S.S. and K.W. Ho (1997), "Market Response to Product-Strategy and CapitalExpenditure Announcements in Singapore: Investment Opportunities and Free Cash Flow", Financial Management, 26: 82-88. 
Chen S.S., K.W. Ho and C.F. Lee (2000), "Investment Opportunities, Free Cash Flow and Market Reaction to International Joint Ventures", Journal of Banking and Finance, 24: 1747-1765.

Chen S.S., K.W. Ho, K.H. IK and C.F. Lee (2002), "How Does Strategic Competition Affect Firm Values? A Study of New Product Announcements", Financial Management, 31: 67-84.

Chen S.S., R.K. Chou and S.F. Chou (2009), "The Impact of Investment Opportunities and Free Cash Flow on Financial Liberalization: A Cross-Firm Analysis of Emerging Economies", Financial Management, 38: 543-566.

Chung, K.H. and S.W. Pruitt (1994), "Simple Approximation of Tobin's Q", Financial Management, 23: 70-74.

Chung, K.H., P. Wright and C. Charoenwong (1998), "Investment Opportunities and Market Reaction to Capital Expenditure Decisions", Journal of Banking and Finance, 22: 4160.

Clements, K.W. and J. Si (2011), "The Investment Project Pipeline: Cost Escalation, LeadTime, Success, Failure and Speed", Australian Journal of Management, forthcoming.

Del Brio E.B., J. Perote and J. Pindado (2003), "Measuring the Impact of Corporate Investment Announcements on Share Prices: The Spanish Experience", Journal of Business Finance and Accounting, 30: 715-747.

Deloitte Access Economics (2010), "Investment Monitor", September.

Denis, D.J. (1994), "Investment Opportunities and the Market Reaction to Equity Offerings", Journal of Financial and Quantitative Analysis, 29: 159-177.

Gregory, R.G. (1976), "Some Implications of the Growth of the Mineral Sector", Australian Journal of Agricultural Economics, 20: 71-91.

Jensen, M. (1986), "Agency Costs of Free Cash Flow, Corporate Finance, and Takeovers," American Economic Review, 76: 323-329.

Keown A.J., P. Laux and J.D. Martin (2005), "The Information Content of Corporate Investment Announcements: The Case of Joint Ventures", Research in Finance, 22: 3371.

Lang, L.H.P. and R.H. Litzenberger (1989), "Dividend Announcement: Cash Flow Signalling vs. Free Cash Flow Hypothesis?" Journal of Financial Economics 24: 181-192.

Lehn K. and A. Poulsen (1989), "Free Cash Flow and Stockholder Gains in Going Private Transactions", Journal of Finance, 44: 771-787.

McConnell, J.J. and C.J. Muscarella (1985), "Corporate Capital Expenditure Decisions and the Market Value of the Firm", Journal of Financial Economics, 14: 399-422.

Pindyck, R.S. (1991), "Irreversibility, Uncertainty, and Investment", Journal of Economic Literature, 29: 1110-1148.

Statman, M. and J.F. Sepe (1989), "Project Termination Announcements and the Market Value of the Firm", Financial Management, 18: 74-81.

Szewczyk, S.H., G.P. Tsetsekos and Z. Zantout (1996), "The Valuation of Corporate R\&D Expenditures: Evidence from Investment Opportunities and Free Cash Flow”, Financial Management, 25: 105-110.

Vogt, S.C. (1997), "Cash Flow and Capital Spending: Evidence from Capital Expenditure Announcements", Financial Management, 26: 44-57. 
TABLE 1

STATES OF PROJECTS

\begin{tabular}{|c|c|}
\hline State & Definition \\
\hline 1. Possible & $\begin{array}{l}\text { Projects which have been announced, but where no early decision } \\
\text { on whether to proceed with the project is likely. }\end{array}$ \\
\hline $\begin{array}{l}\text { 2. Under } \\
\text { consideration }\end{array}$ & $\begin{array}{l}\text { Where a decision whether to proceed with the project is expected in } \\
\text { the reasonably near future. }\end{array}$ \\
\hline 3. Committed & $\begin{array}{l}\text { A decision to proceed has been announced but construction has not } \\
\text { yet started. }\end{array}$ \\
\hline $\begin{array}{l}\text { 4. Under } \\
\text { construction }\end{array}$ & Work has commenced on the project. \\
\hline 5. Completed & Completed in the current quarter. \\
\hline 6. Deleted & Deleted in the current quarter. \\
\hline
\end{tabular}

TABLE 3

SUMMARY OF PROJECTS INCLUDED AND EXCLUDED

\begin{tabular}{lccc}
\hline \hline \multicolumn{1}{c}{ Classification } & $\begin{array}{c}\text { Number of listed } \\
\text { firms }\end{array}$ & $\begin{array}{c}\text { Number of } \\
\text { projects of listed firms }\end{array}$ & $\begin{array}{c}\text { Number of } \\
\text { events } \\
(1)\end{array}$ \\
$(2)$ & $(3)$ & 442 \\
\hline IM database & 197 & 220 & 825 \\
Included in the sample & 134 & 222 & 301 \\
Not included in the sample & 63 & 524 \\
\hline
\end{tabular}

TABLE 4

THE DISTRIBUTION OF PROJECTS BY INDUSTRY

\begin{tabular}{|c|c|c|c|c|c|}
\hline \multirow[t]{2}{*}{$\begin{array}{l}\text { Industry/ Sub-industry } \\
\end{array}$} & \multicolumn{2}{|c|}{ Number of projects } & \multicolumn{3}{|c|}{ Cost of projects } \\
\hline & Number & $\begin{array}{l}\text { Percentage } \\
\text { of total }\end{array}$ & $\begin{array}{l}\text { Total } \\
(\$ \mathrm{~m})\end{array}$ & $\begin{array}{l}\text { Percentage } \\
\text { of total }\end{array}$ & $\begin{array}{l}\text { Average cost per } \\
\text { project }(\$ \mathrm{~m})\end{array}$ \\
\hline \multicolumn{6}{|l|}{$\overline{\text { Mining }}$} \\
\hline Coal & 22 & 10 & 9,388 & 8 & 426 \\
\hline Iron ore & 30 & 14 & 28,686 & 24 & 956 \\
\hline Gold & 30 & 14 & 5,224 & 4 & 174 \\
\hline Copper & 8 & 4 & 930 & 1 & 116 \\
\hline Nickel & 16 & 7 & 3,954 & 3 & 247 \\
\hline Oil and gas extraction & 38 & 17 & 52,806 & 45 & 1,389 \\
\hline Other & 44 & 21 & 6575 & 6 & 149 \\
\hline Total & 188 & 87 & 107,563 & 91 & 572 \\
\hline Electricity supply & 28 & 13 & 10,149 & 9 & 362 \\
\hline Total & 220 & 100 & 117,712 & 100 & 535 \\
\hline
\end{tabular}


TABLE 2

EXAMPLES OF PROJECTS

(States: $1=$ possible, $2=$ consideration, $3=$ committed, $4=$ construction, $5=$ completed; cost in parentheses, $\$ \mathrm{~m}$ )

\begin{tabular}{|c|c|c|c|c|c|c|c|c|c|c|c|c|c|c|c|c|c|}
\hline $\begin{array}{l}\text { Project } \\
\text { number }\end{array}$ & 2005:1 & $2005: 2$ & $2005: 3$ & $2005: 4$ & 2006:1 & 2006:2 & $2006: 3$ & 2006:4 . & $2008: 1$ & 2008:2 & 2008:3 & 2008:4 & 2009:1 & 2009:2 & 2009:3 & 2009:4 & 2010:1 \\
\hline 1. 8048 & & & & $\begin{array}{c}2 \\
(1,700)\end{array}$ & $\begin{array}{c}2 \\
(1,700)\end{array}$ & $\begin{array}{c}4 \\
(1,700)\end{array}$ & $\begin{array}{c}4 \\
(1,700)\end{array}$ & $\begin{array}{c}4 \\
(2,050)\end{array}$ & $\begin{array}{c}4 \\
(2,050)\end{array}$ & $\begin{array}{c}4 \\
(2,050)\end{array}$ & $\begin{array}{c}5 \\
(2,050)\end{array}$ & & & & & & \\
\hline 2. 7708 & & $\begin{array}{c}1 \\
(870)\end{array}$ & $\begin{array}{c}1 \\
(870)\end{array}$ & $\begin{array}{c}1 \\
(870)\end{array}$ & $\begin{array}{c}2 \\
(870)\end{array}$ & $\begin{array}{c}2 \\
(870)\end{array}$ & $\begin{array}{c}2 \\
(870)\end{array}$ & $\begin{array}{c}2 \\
(870)\end{array}$ & $\begin{array}{c}2 \\
(870)\end{array}$ & $\begin{array}{c}2 \\
(870)\end{array}$ & $\begin{array}{c}2 \\
(870)\end{array}$ & $\begin{array}{c}2 \\
(870)\end{array}$ & $\begin{array}{c}2 \\
(870)\end{array}$ & $\begin{array}{c}2 \\
(870)\end{array}$ & $\begin{array}{c}2 \\
(870)\end{array}$ & $\begin{array}{c}2 \\
(870)\end{array}$ & $\begin{array}{c}5 \\
(870)\end{array}$ \\
\hline 3. 7494 & $\begin{array}{c}2 \\
\text { (NA) }\end{array}$ & $\begin{array}{c}2 \\
\text { (NA) }\end{array}$ & $\begin{array}{c}2 \\
(\mathrm{NA})\end{array}$ & $\begin{array}{c}2 \\
(1,500)\end{array}$ & $\begin{array}{c}2 \\
(1,500)\end{array}$ & $\begin{array}{c}2 \\
(1,500)\end{array}$ & $\begin{array}{c}4 \\
(1,500)\end{array}$ & $\begin{array}{c}4 \\
(1,600)\end{array}$ & $\begin{array}{c}4 \\
(1,600)\end{array}$ & $\begin{array}{c}4 \\
(1,600)\end{array}$ & $\begin{array}{c}4 \\
(1,600)\end{array}$ & $\begin{array}{c}5 \\
(1,600)\end{array}$ & & & & & \\
\hline 4. 7449 & $\begin{array}{c}1 \\
(700) \\
\end{array}$ & $\begin{array}{c}2 \\
(700) \\
\end{array}$ & $\begin{array}{c}2 \\
(700) \\
\end{array}$ & $\begin{array}{c}2 \\
(700) \\
\end{array}$ & $\begin{array}{c}2 \\
(1,000) \\
\end{array}$ & $\begin{array}{c}2 \\
(1,000) \\
\end{array}$ & $\begin{array}{c}2 \\
(1,000) \\
\end{array}$ & $\begin{array}{c}2 \\
(1,100) \\
\end{array}$ & $\begin{array}{c}2 \\
(1,700) \\
\end{array}$ & $\begin{array}{c}3 \\
(1,700) \\
\end{array}$ & $\begin{array}{c}3 \\
(1,700) \\
\end{array}$ & $\begin{array}{c}3 \\
(1,700) \\
\end{array}$ & $\begin{array}{c}3 \\
(1,700) \\
\end{array}$ & $\begin{array}{c}3 \\
(1,800) \\
\end{array}$ & $\begin{array}{c}3 \\
(1,800) \\
\end{array}$ & $\begin{array}{c}4 \\
(1,800) \\
\end{array}$ & $\begin{array}{c}4 \\
(1,800) \\
\end{array}$ \\
\hline
\end{tabular}

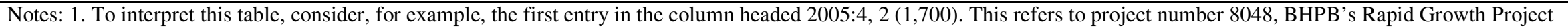
3 (see note 2 below). This project first enters the IM database in the consideration state in the fourth quarter of 2005 . At that date, this project is estimated to cost $\$ 1,700 \mathrm{~m}$.

2. The project details are as follows:

\begin{tabular}{lllll} 
Project No. & Company & Project description & Industry & Sub-industry \\
\hline 8048 & BHP Billiton & Rapid Growth Project 3 & Mining & Iron ore \\
7708 & Origin Energy Ltd & Spring Gully Power Station project & Electricity, Gas \& Water & Electricity supply \\
7494 & Woodside & Angel gas field development & Mining & Oil \& Gas extraction \\
7449 & Gindalbie & Development of Mt Karara iron ore mine & Mining & Iron ore \\
\hline
\end{tabular}


TABLE 5

THE DISTRIBUTION OF EVENTS BY STATE

(Number of events)

\begin{tabular}{l|ccccc|c}
\hline \hline \multirow{1}{*}{ Exiting state } & \multicolumn{5}{c|}{ Entering state } & Total \\
\cline { 2 - 6 } \multicolumn{1}{c|}{$(1)$} & Possible & Consideration & Committed & Construction & Completed & \\
1. New & 45 & $(3)$ & $(4)$ & $(5)$ & $(6)$ & $(7)$ \\
2. Possible & & 60 & 21 & 11 & 0 & 137 \\
3. Consideration & & 24 & 10 & 5 & 0 & 39 \\
4. Committed & & & 35 & 13 & 4 & 52 \\
5. Construction & & & & 20 & 0 & 20 \\
\hline Total & 45 & 84 & 66 & 49 & 53 & 53 \\
\hline
\end{tabular}

TABLE 6

DESCRIPTIVE STATISTICS

\begin{tabular}{|c|c|c|c|c|c|}
\hline $\begin{array}{c}\text { Variables } \\
\text { (1) }\end{array}$ & $\begin{array}{c}\text { Mean } \\
(2)\end{array}$ & $\begin{array}{c}\text { Median } \\
\text { (3) }\end{array}$ & $\begin{array}{l}\text { Min } \\
\text { (4) }\end{array}$ & $\begin{array}{l}\text { Max } \\
\text { (5) }\end{array}$ & $\begin{array}{c}\text { Standard } \\
\text { deviation } \\
(6)\end{array}$ \\
\hline Firm market capitalisation $(\$ M)$ & 1,800 & 140 & 4 & 79,157 & 7,975 \\
\hline Project cost $(\$ M)$ & 535 & 158 & 5 & 11,200 & 1,320 \\
\hline The number of projects per firm & 1.64 & 1 & 1 & 12 & 1.8 \\
\hline The number of announcements per firm & 2.24 & 1 & 1 & 20 & 2.61 \\
\hline The number of announcements per project & 1.37 & 1 & 1 & 4 & 0.7 \\
\hline
\end{tabular}


TABLE 7

DAILY AND CUMULATIVE ABNORMAL RETURNS (Percent)

\begin{tabular}{cccccccc}
\hline \hline & & \multicolumn{9}{c}{ State } \\
\cline { 3 - 7 } & Total & Possible & Consideration & Committed & Construction & Completed \\
& $(\mathrm{N}=301)$ & $(\mathrm{N}=45)$ & $(\mathrm{N}=84)$ & $(\mathrm{N}=66)$ & $(\mathrm{N}=49)$ & $(\mathrm{N}=57)$ & $(7)$ \\
\hline
\end{tabular}

Day relative to announcement day

\begin{tabular}{rrrrrrr}
-5 & $0.02(0.23)$ & $0.71(0.62)$ & $-0.12(0.48)$ & $-0.31(0.51)$ & $0.10(0.38)$ & $-0.03(0.56)$ \\
-4 & $-0.09(0.21)$ & $-0.23(0.51)$ & $0.10(0.53)$ & $0.66(0.36)$ & $-0.44(0.33)$ & $-0.86(0.43)$ \\
-3 & $0.31(0.21)$ & $0.97(0.51)$ & $0.52(0.53)$ & $0.49(0.37)$ & $-0.06(0.38)$ & $-0.43(0.37)$ \\
-2 & $0.08(0.19)$ & $0.37(0.64)$ & $-0.19(0.40)$ & $0.25(0.42)$ & $0.16(0.38)$ & $-0.04(0.33)$ \\
-1 & $0.32(0.23)$ & $0.17(0.62)$ & $-0.16(0.37)$ & $0.45(0.51)$ & $1.05(0.58)$ & $0.35(0.56)$ \\
\hline 0 & $1.66(0.37)$ & $2.44(1.07)$ & $2.52(0.79)$ & $0.34(0.77)$ & $0.82(0.72)$ & $2.01(0.75)$ \\
\hline+1 & $0.34(0.24)$ & $-0.94(0.60)$ & $0.38(0.50)$ & $0.25(0.46)$ & $0.81(0.52)$ & $1.02(0.60)$ \\
+2 & $0.08(0.24)$ & $0.18(0.59)$ & $0.28(0.66)$ & $-0.11(0.41)$ & $-0.08(0.31)$ & $0.05(0.37)$ \\
+3 & $-0.14(0.22)$ & $-0.24(0.56)$ & $-0.30(0.59)$ & $0.06(0.35)$ & $-0.13(0.37)$ & $-0.05(0.33)$ \\
+4 & $-0.44(0.21)$ & $-1.06(0.55)$ & $-0.39(0.52)$ & $0.04(0.36)$ & $-0.12(0.34)$ & $-0.86(0.45)$ \\
+5 & $-0.32(0.20)$ & $-0.46(0.48)$ & $-0.75(0.47)$ & $-0.42(0.35)$ & $-0.13(0.38)$ & $0.36(0.48)$
\end{tabular}

A. Daily abnormal returns
Event window

$[-1,+1]$
$[-10,-1]$
$[+1,+10]$
$[-10,+10]$
Event day
Possible
Consideration
Committed
Construction
Completed

(ii) 3-day window $[-1,+1]$

1. Possible
2. Consideration
3. Committed
4. Construction
5. Completed

(iii) Entire window $[-10 .+10]$

B. Cumulative abnormal returns

\begin{tabular}{rrrr|}
\hline $2.68(0.81)$ & $1.07(0.82)$ & $2.68(0.82)$ & $3.38(0.94)$ \\
$-1.00(1.11)$ & $2.00(1.11)$ & $0.46(1.32)$ & $-0.16(1.25)$ \\
$0.93(1.46)$ & $-0.32(1.04)$ & $-0.83(1.45)$ & $-0.73(1.31)$ \\
$2.38(2.06)$ & $2.01(1.70)$ & $0.18(2.07)$ & $0.89(1.89)$
\end{tabular}

\section{C. $\underline{\text { Pair-wise differences }}$}

$\begin{array}{ccccc}- & -0.08(1.34) & 2.10(1.28) & 1.62(1.27) & 0.42(1.27) \\ 0.08(1.34) & - & 2.18(1.13) & 1.70(1.18) & 0.50(1.15) \\ -2.10(1.28) & -2.18(1.13) & - & -0.48(1.09) & -1.67(1.08) \\ -1.62(1.27) & -1.70(1.18) & 0.48(1.09) & - & -1.19(1.05) \\ -0.42(1.27) & -0.50(1.15) & 1.67(1.08) & 1.19(1.05) & - \\ & & & & \\ - & & & & -1.45(1.41) \\ 0.75(1.34) & -0.75(1.34) & 0.86(1.31) & -0.75(1.31) & -0.70(1.25) \\ -0.86(1.31) & -1.61(1.17) & - & -1.61(1.19) & -2.31(1.24) \\ 0.75(1.31) & 0.00(1.23) & 1.61(1.19) & - & -0.70(1.27) \\ 1.45(1.41) & 0.70(1.25) & 2.31(1.24) & 0.70(1.27) & -\end{array}$

\begin{tabular}{lccccc} 
1. Possible & - & $-2.45(3.14)$ & $-2.08(2.57)$ & $-0.25(2.81)$ & $-0.96(2.70)$ \\
2. Consideration & $2.45(3.14)$ & - & $0.37(2.77)$ & $2.20(3.13)$ & $1.49(2.95)$ \\
3. Committed & $2.08(2.57)$ & $-0.37(2.77)$ & - & $1.83(2.66)$ & $1.12(2.53)$ \\
4. Construction & $0.25(2.81)$ & $-2.20(3.13)$ & $-1.83(2.66)$ & - & $-0.71(2.80)$ \\
5. Completed & $0.96(2.70)$ & $-1.49(2.95)$ & $-1.12(2.53)$ & $0.71(2.80)$ & - \\
\hline
\end{tabular}

Notes: 1.Standard errors are shown in parentheses.

2. In Panels B and C, the notation " $[\mathrm{x}, \mathrm{y}]$ " for the event window means the window opens and closes $\mathrm{x}$ and y days before and after the event, respectively. 
TABLE 8

DAILY AND CUMULATIVE ABNORMAL RETURNS: MARKET-ADJUSTED RETURNS

(Percent)

\begin{tabular}{|c|c|c|c|c|c|c|}
\hline \multirow[b]{2}{*}{ (1) } & \multirow[b]{2}{*}{$\begin{array}{c}\text { Total } \\
(\mathrm{N}=301) \\
(2)\end{array}$} & \multicolumn{5}{|c|}{ State } \\
\hline & & $\begin{array}{c}\text { Possible } \\
(\mathrm{N}=45) \\
(3)\end{array}$ & $\begin{array}{c}\text { Consideration } \\
(\mathrm{N}=84) \\
(4)\end{array}$ & $\begin{array}{l}\text { Committed } \\
(\mathrm{N}=66) \\
(5)\end{array}$ & $\begin{array}{l}\text { Construction } \\
(\mathrm{N}=49) \\
(6)\end{array}$ & $\begin{array}{l}\text { Completed } \\
(\mathrm{N}=57) \\
(7)\end{array}$ \\
\hline $\begin{array}{l}\text { Day relative to } \\
\text { announcement }\end{array}$ & & & A. Daily abnor & return & & \\
\hline-5 & $0.21(0.23)$ & $1.17(0.65)$ & $0.21(0.47)$ & $-0.27(0.50)$ & $0.09(0.34)$ & $0.13(0.60)$ \\
\hline-4 & $0.05(0.21)$ & $-0.10(0.53)$ & $0.45(0.51)$ & $0.59(0.37)$ & $-0.38(0.35)$ & $-0.67(0.44)$ \\
\hline-3 & $0.42(0.21)$ & $1.15(0.56)$ & $0.87(0.52)$ & $0.52(0.36)$ & $-0.10(0.40)$ & $-0.50(0.40)$ \\
\hline-2 & $0.17(0.20)$ & $0.68(0.66)$ & $0.00(0.40)$ & $0.13(0.42)$ & $0.37(0.41)$ & $-0.12(0.36)$ \\
\hline-1 & $0.41(0.23)$ & $0.32(0.60)$ & $-0.01(0.39)$ & $0.39(0.52)$ & $1.21(0.57)$ & $0.45(0.58)$ \\
\hline 0 & $1.75(0.35)$ & $2.44(1.07)$ & $2.51(0.79)$ & $0.82(0.53)$ & $0.82(0.72)$ & $1.98(0.73)$ \\
\hline+1 & $0.53(0.24)$ & $-0.70(0.60)$ & $0.54(0.49)$ & $0.50(0.48)$ & $0.96(0.55)$ & $1.18(0.60)$ \\
\hline+2 & $0.20(0.24)$ & $0.47(0.60)$ & $0.43(0.66)$ & $-0.04(0.40)$ & $0.06(0.31)$ & $0.04(0.36)$ \\
\hline+3 & $0.05(0.22)$ & $0.07(0.56)$ & $-0.22(0.59)$ & $0.22(0.35)$ & $0.35(0.45)$ & $0.00(0.36)$ \\
\hline+4 & $-0.28(0.21)$ & $-0.83(0.54)$ & $-0.02(0.53)$ & $-0.03(0.36)$ & $-0.14(0.34)$ & $-0.62(0.42)$ \\
\hline+5 & $-0.15(0.20)$ & $-0.35(0.48)$ & $-0.36(0.45)$ & $-0.33(0.34)$ & $-0.02(0.39)$ & $0.38(0.49)$ \\
\hline Event window & & & B. Cumulative & ormal return & & \\
\hline$[-1,+1]$ & $2.71(0.41)$ & $2.29(1.10)$ & $3.02(0.83)$ & $1.61(0.86)$ & $2.98(0.88)$ & $3.61(0.96)$ \\
\hline$[-10,-1]$ & $1.42(0.54)$ & $2.45(1.48)$ & $1.19(1.10)$ & $2.09(1.00)$ & $1.03(1.19)$ & $0.50(1.40)$ \\
\hline$[+1,+10]$ & $0.85(0.61)$ & $-1.52(1.49)$ & 2.85 (1.49) & $0.62(1.04)$ & $0.78(1.33)$ & $0.09(1.22)$ \\
\hline$[-10,+10]$ & $4.01(0.84)$ & $3.39(1.75)$ & $6.77(2.00)$ & $3.60(1.51)$ & $2.63(1.77)$ & $2.11(1.93)$ \\
\hline
\end{tabular}

Note: Standard errors are shown in parentheses.

\section{TABLE 9}

DAILY AND CUMULATIVE ABNORMAL RETURNS: 240-DAY ESTIMATION WINDOW

(Percent)

\begin{tabular}{|c|c|c|c|c|c|c|}
\hline \multirow[b]{2}{*}{ (1) } & \multirow[b]{2}{*}{$\begin{array}{c}\text { Total } \\
(\mathrm{N}=301) \\
(2)\end{array}$} & \multicolumn{5}{|c|}{ State } \\
\hline & & $\begin{array}{c}\text { Possible } \\
(\mathrm{N}=45) \\
(3)\end{array}$ & $\begin{array}{c}\text { Consideration } \\
(\mathrm{N}=84) \\
(4)\end{array}$ & $\begin{array}{l}\text { Committed } \\
(\mathrm{N}=66) \\
(5)\end{array}$ & $\begin{array}{c}\text { Construction } \\
(\mathrm{N}=49) \\
(6)\end{array}$ & $\begin{array}{c}\text { Completed } \\
(\mathrm{N}=57) \\
(7)\end{array}$ \\
\hline $\begin{array}{l}\text { Day relative to } \\
\text { announcement }\end{array}$ & \multicolumn{6}{|c|}{ A. Daily abnormal return } \\
\hline-5 & $0.03(0.24)$ & $0.78(0.75)$ & $-0.14(0.50)$ & $-0.29(0.50)$ & $0.01(0.36)$ & $0.16(0.58)$ \\
\hline-4 & $-0.08(0.21)$ & $0.12(0.53)$ & $0.03(0.52)$ & $0.48(0.33)$ & $-0.43(0.35)$ & $-0.73(0.43)$ \\
\hline-3 & $0.15(0.20)$ & $0.62(0.55)$ & $0.16(0.49)$ & $0.43(0.38)$ & $-0.10(0.40)$ & $-0.28(0.38)$ \\
\hline-2 & $0.11(0.21)$ & $0.51(0.76)$ & $-0.15(0.45)$ & $0.35(0.41)$ & $0.06(0.40)$ & $-0.03(0.33)$ \\
\hline-1 & $0.39(0.23)$ & $0.35(0.52)$ & $-0.15(0.45)$ & $0.43(0.51)$ & $1.19(0.61)$ & $0.47(0.55)$ \\
\hline 0 & $1.68(0.35)$ & $2.84(1.23)$ & $2.07(0.73)$ & $0.79(0.58)$ & $1.01(0.74)$ & $1.97(0.76)$ \\
\hline+1 & $0.36(0.24)$ & $-0.87(0.66)$ & $0.57(0.48)$ & $-0.06(0.35)$ & $0.77(0.55)$ & $0.98(0.63)$ \\
\hline+2 & $-0.09(0.24)$ & $-0.27(0.61)$ & $-0.10(0.66)$ & $-0.15(0.41)$ & $-0.16(0.30)$ & $0.18(0.35)$ \\
\hline+3 & $0.05(0.22)$ & $0.52(0.57)$ & $-0.08(0.61)$ & $0.14(0.35)$ & $-0.10(0.39)$ & $-0.08(0.34)$ \\
\hline+4 & $-0.50(0.21)$ & $-1.40(0.55)$ & $-0.49(0.49)$ & $-0.02(0.37)$ & $-0.11(0.37)$ & $-0.81(0.44)$ \\
\hline+5 & $-0.75(0.20)$ & $-0.58(0.53)$ & $-0.92(0.47)$ & $-0.35(0.34)$ & $0.00(0.37)$ & $0.33(0.50)$ \\
\hline Event window & \multicolumn{6}{|c|}{ B. Cumulative abnormal return } \\
\hline$[-1,+1]$ & $2.43(0.44)$ & $2.32(1.31)$ & $2.50(0.87)$ & $1.16(0.95)$ & $2.97(0.86)$ & $3.42(0.96)$ \\
\hline$[-10,-1]$ & $0.37(0.58)$ & $1.57(1.72)$ & $-1.16(1.18)$ & $1.84(1.06)$ & $0.44(1.30)$ & $-0.02(1.38)$ \\
\hline$[+1,+10]$ & $-0.48(0.65)$ & $-3.04(1.41)$ & $0.81(1.70)$ & $-0.70(0.96)$ & $-0.40(1.39)$ & $-0.45(1.26)$ \\
\hline$[-10,+10]$ & $1.57(0.93)$ & $1.36(2.07)$ & $1.72(2.35)$ & $1.94(1.54)$ & $1.04(2.10)$ & $1.51(1.87)$ \\
\hline
\end{tabular}

Note: Standard error is shown in parentheses. 
TABLE 10

VALUE OF RESOURCE PROJECTS: VARIOUS EVENT WINDOWS

\begin{tabular}{|c|c|c|c|c|c|c|}
\hline \multirow{2}{*}{$\begin{array}{c}\text { State } \\
(1)\end{array}$} & \multirow{2}{*}{$\begin{array}{c}\text { Number of } \\
\text { events } \\
\text { (2) }\end{array}$} & \multicolumn{5}{|c|}{ Value of projects } \\
\hline & & $\begin{array}{c}\text { Mean } \\
\text { (3) }\end{array}$ & $\begin{array}{c}\text { Median } \\
\text { (4) }\end{array}$ & $\begin{array}{c}\text { Standard } \\
\text { deviation } \\
\text { (5) }\end{array}$ & $\begin{array}{c}\text { Total } \\
\text { (6) }\end{array}$ & $\begin{array}{l}\text { Percent of } \\
\text { project cost } \\
\text { (7) }\end{array}$ \\
\hline \multicolumn{7}{|c|}{ A. Event day $[0,0]$} \\
\hline Total & 301 & 23 & 1 & 179 & 6,903 & 6 \\
\hline Possible & 45 & 52 & 1 & 327 & 2,375 & 5 \\
\hline Consideration & 84 & 10 & 1 & 87 & 905 & 2 \\
\hline Committed & 66 & 17 & 1 & 154 & 1,132 & 4 \\
\hline Construction & 49 & 24 & 0 & 194 & 1,152 & 4 \\
\hline Completed & 57 & 23 & 3 & 125 & 1,337 & 8 \\
\hline \multicolumn{7}{|c|}{ B. 3 -day window $[-1,+1]$} \\
\hline Total & 301 & 76 & 2 & 593 & 22,934 & 19 \\
\hline Possible & 45 & 24 & 1 & 425 & 1,066 & 2 \\
\hline Consideration & 84 & 36 & 1 & 259 & 3,018 & 7 \\
\hline Committed & 66 & 80 & 2 & 383 & 5,261 & 16 \\
\hline Construction & 49 & 210 & 7 & 1,282 & 10,290 & 32 \\
\hline Completed & 57 & 58 & 4 & 199 & 3,295 & 20 \\
\hline \multicolumn{7}{|c|}{ C. Entire window $[-10,+10]$} \\
\hline Total & 301 & 25 & 1 & 971 & 7,694 & 7 \\
\hline Possible & 45 & -148 & -3 & 635 & $-6,553$ & -14 \\
\hline Consideration & 84 & 2 & 1 & 917 & 138 & 0.3 \\
\hline Committed & 66 & -101 & 8 & 1,180 & $-6,567$ & -20 \\
\hline Construction & 49 & 238 & -2 & 1,329 & 11,694 & 37 \\
\hline Completed & 57 & -3 & 3 & 559 & -155 & -1 \\
\hline
\end{tabular}

Note: The units of entries in columns 3 to 6 are $\$ \mathrm{~m}$. 
TABLE 11

CUMULATIVE ABNORMAL RETURNS, FIRM AND PROJECT

CHARACTERISTICS

$$
C A R_{i}=\beta_{1}+\beta_{2} M_{i}+\beta_{3} J V_{i}+\beta_{4} Q_{i}+\beta_{5} F_{i}+\varepsilon_{i}
$$

\begin{tabular}{|c|c|c|c|c|}
\hline $\begin{array}{l}\text { Intercept } \\
\text { (1) }\end{array}$ & $\begin{array}{c}\text { Mining } \\
\text { industry } \\
\text { (2) }\end{array}$ & $\begin{array}{c}\text { Joint } \\
\text { venture } \\
(3)\end{array}$ & $\begin{array}{c}\text { High } \\
\text { Tobin's q } \\
(4)\end{array}$ & $\begin{array}{l}\text { High free } \\
\text { cash flow } \\
\text { (5) }\end{array}$ \\
\hline \multicolumn{5}{|c|}{ 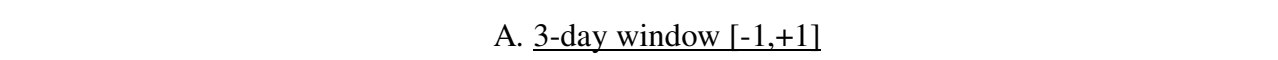 } \\
\hline $2.35(0.40)$ & - & - & - & - \\
\hline $1.51(0.49)$ & $1.19(0.86)$ & - & - & - \\
\hline $2.62(0.49)$ & & $-0.95(0.87)$ & - & - \\
\hline $2.92(1.03)$ & & & $-0.62(1.19)$ & - \\
\hline $3.08(0.72)$ & & & & $-1.72(0.81)$ \\
\hline \multicolumn{5}{|c|}{ B. Pre-event window $[-10,-1]$} \\
\hline $0.25(0.55)$ & - & - & - & - \\
\hline $0.91(0.67)$ & $-0.94(1.21)$ & - & - & - \\
\hline $0.01(0.69)$ & & $0.84(1.22)$ & - & - \\
\hline $1.48(1.42)$ & & & $-1.25(1.65)$ & - \\
\hline $0.08(0.91)$ & & & & $0.43(1.16)$ \\
\hline \multicolumn{5}{|c|}{ C. Post-event window $[+1,+10]$} \\
\hline$-0.49(0.63)$ & - & - & - & - \\
\hline $0.39(0.91)$ & $-1.26(1.37)$ & - & - & - \\
\hline$-1.22(0.73)$ & & $2.51(1.38)$ & - & - \\
\hline$-0.42(1.96)$ & & & $0.01(1.87)$ & - \\
\hline$-0.64(1.03)$ & & & & $0.07(1.29)$ \\
\hline \multicolumn{5}{|c|}{ D. Entire window $[-10,+10]$} \\
\hline $1.29(0.89)$ & - & - & - & - \\
\hline $2.08(1.33)$ & $-1.22(1.94)$ & - & - & - \\
\hline $0.69(1.07)$ & & $2.09(1.95)$ & - & - \\
\hline $2.74(2.51)$ & & & $-1.42(2.64)$ & - \\
\hline $1.65(1.47)$ & & & & $-0.86(1.83)$ \\
\hline
\end{tabular}

Notes: 1. Standard errors are shown in parentheses.

2. The mean of three dummies used here are: mining industry 0.88 , joint venture 0.29 and Tobin's q 2.36 and the median of free cash flow level is -0.6 . 
TABLE 12

CUMULATIVE ABNORMAL RETURNS, PROJECT COST AND MARKET CAPITALISATION

$$
C A R_{i}=\lambda_{1}+\lambda_{2} \log C_{i}+\lambda_{3} \log M k t_{i}+\varepsilon_{i},
$$

\begin{tabular}{|c|c|c|c|c|}
\hline $\begin{array}{l}\text { Intercept } \\
\text { (1) }\end{array}$ & $\begin{array}{l}\text { Log of } \\
\text { project cost } \\
\text { (2) }\end{array}$ & $\begin{array}{l}\text { Log of market } \\
\text { capitalization } \\
\text { (3) }\end{array}$ & $\begin{array}{c}\text { F-test } \\
\lambda_{1}=-\lambda_{2} \\
\text { (4) }\end{array}$ & $\begin{array}{c}\text { Log ratio } \\
\text { project size/capitalization } \\
(5)\end{array}$ \\
\hline \multicolumn{5}{|c|}{ A. Total $(\mathrm{N}=301)$} \\
\hline $2.35(0.40)$ & - & - & - & - \\
\hline $1.97(1.47)$ & $0.80(0.31)$ & $-0.61(0.18)$ & 0.51 & - \\
\hline $2.96(0.42)$ & - & - & - & $0.63(0.18)$ \\
\hline \multicolumn{5}{|c|}{ B. Possible $(\mathrm{N}=45)$} \\
\hline $1.92(1.04)$ & - & - & - & - \\
\hline$-8.68(3.77)$ & $2.08(1.48)$ & $-0.22(0.36)$ & 8.53 & - \\
\hline $1.95(1.03)$ & - & - & - & $0.43(0.39)$ \\
\hline \multicolumn{5}{|c|}{ C. $\underline{\text { Consideration }(\mathrm{N}=84)}$} \\
\hline $2.68(0.81)$ & - & - & - & - \\
\hline $4.15(2.92)$ & $0.42(0.67)$ & $-0.68(0.37)$ & 0.23 & - \\
\hline $2.79(0.80)$ & - & - & - & $0.66(0.37)$ \\
\hline \multicolumn{5}{|c|}{ D. $\underline{\text { Committed }(\mathrm{N}=66)}$} \\
\hline $1.07(0.82)$ & - & - & - & - \\
\hline $0.14(2.80)$ & $0.97(0.78)$ & $-0.60(0.45)$ & 0.44 & - \\
\hline $1.99(1.11)$ & - & - & - & $0.55(0.44)$ \\
\hline \multicolumn{5}{|c|}{ E. Construction $(\mathrm{N}=49)$} \\
\hline $2.68(0.82)$ & - & - & - & - \\
\hline $3.59(3.26)$ & $0.45(0.65)$ & $-0.49(0.45)$ & 0.00 & - \\
\hline $3.43(1.06)$ & - & - & - & $0.48(0.43)$ \\
\hline \multicolumn{5}{|c|}{ F. Completed $(\mathrm{N}=57)$} \\
\hline $3.38(0.94)$ & - & - & - & - \\
\hline $5.27(3.58)$ & $2.27(1.02)$ & $-2.00(0.58)$ & 0.14 & - \\
\hline $6.53(1.26)$ & - & - & - & $1.96(0.57)$ \\
\hline
\end{tabular}

Notes: 1. 3-day cumulative abnormal returns are used here.

2. Standard errors are shown in parentheses.

3. The number of observations is indicated by $\mathrm{N}$. 


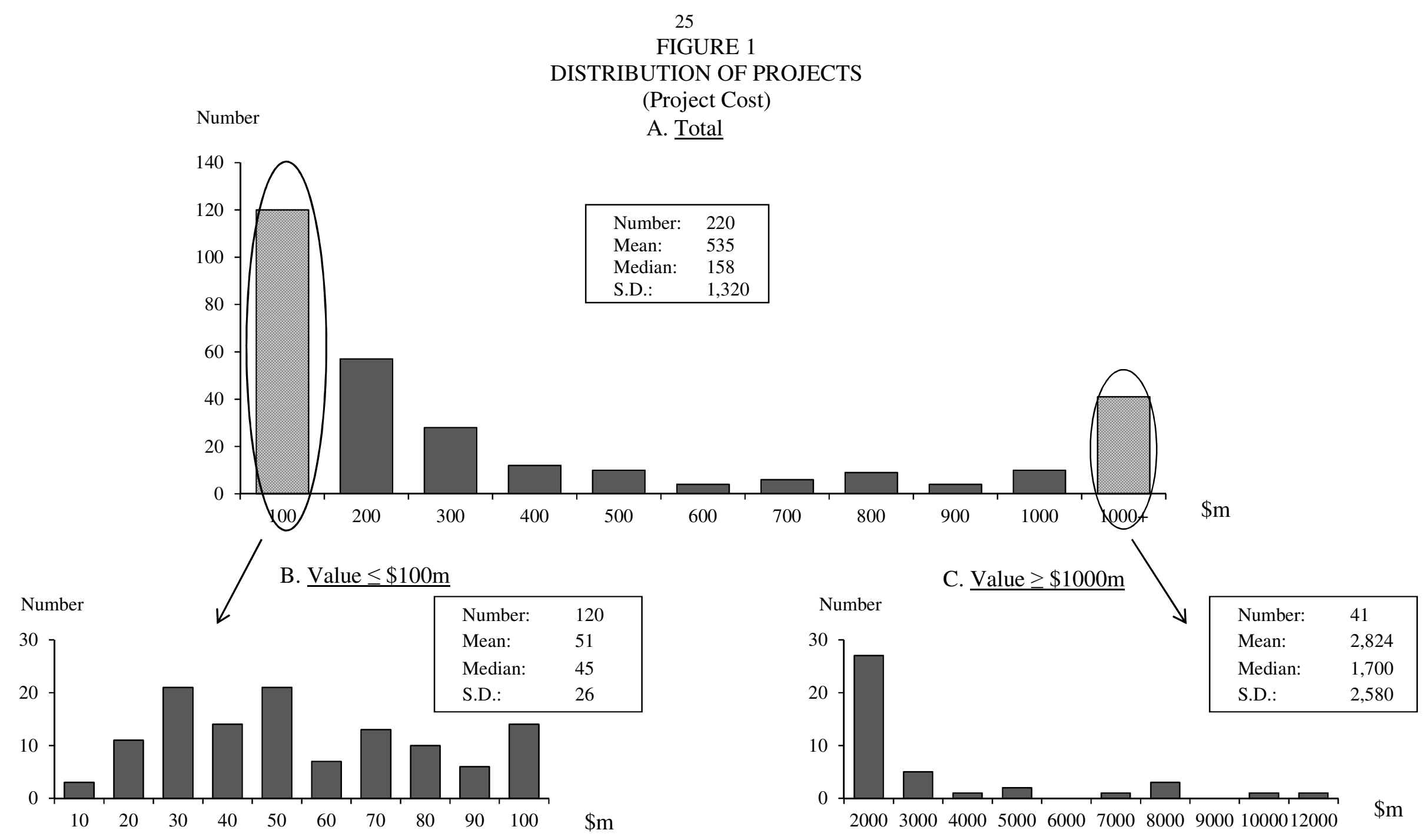

Note: The figure displays the distribution of the project cost at each announcement. 
FIGURE 2

SIZE DISTRIBUTION OF FIRMS

(Market Capitalisation)

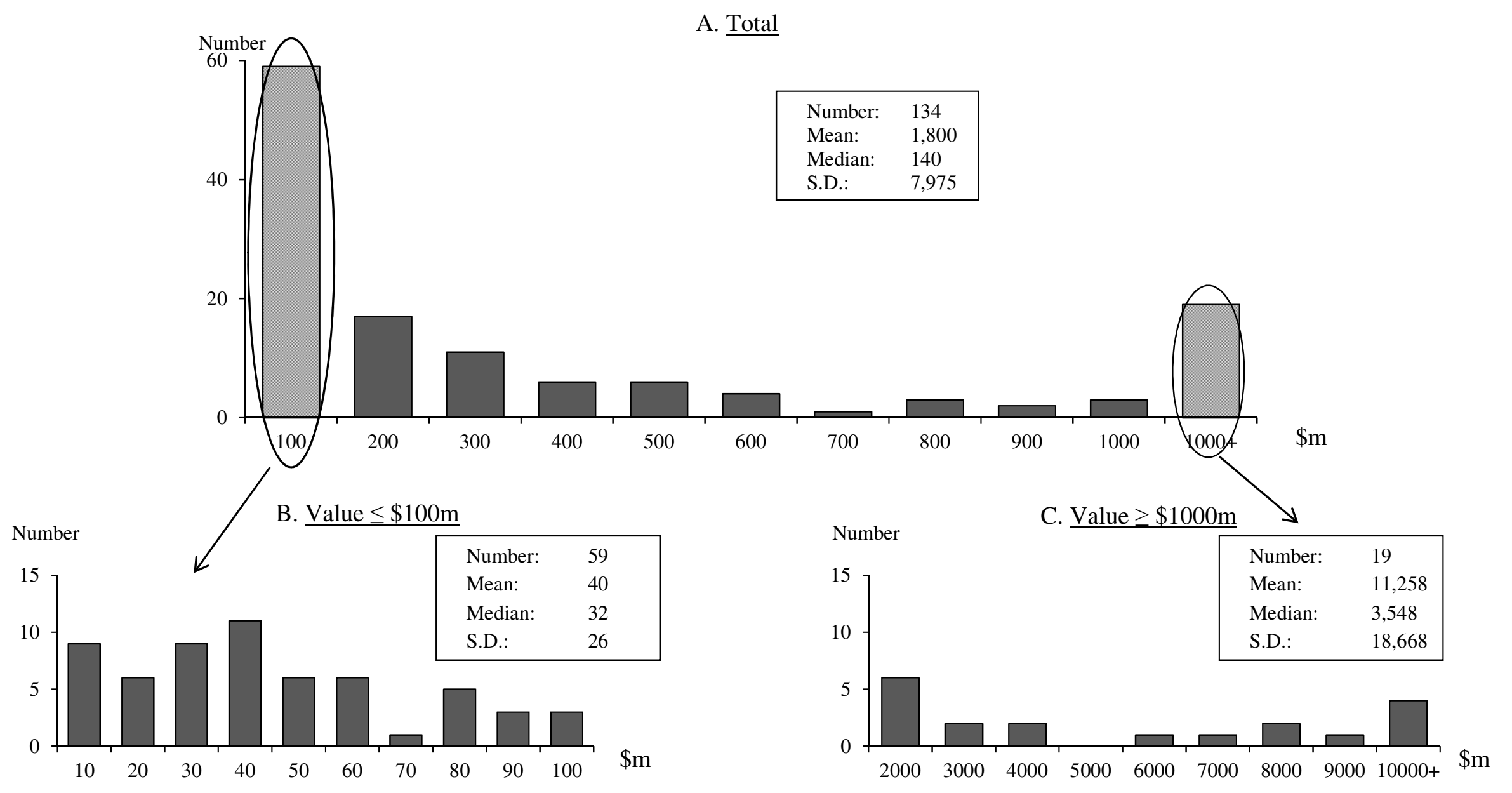

Note: This figure is the distribution of firm size measured by market capitalisation at the time of announcement. For firms with multiple announcements, we use average market capitalisation. 
27

FIGURE 3

PROJECT: SIZE DISTRIBUTION

(Ratio of project cost to market capitalisation)

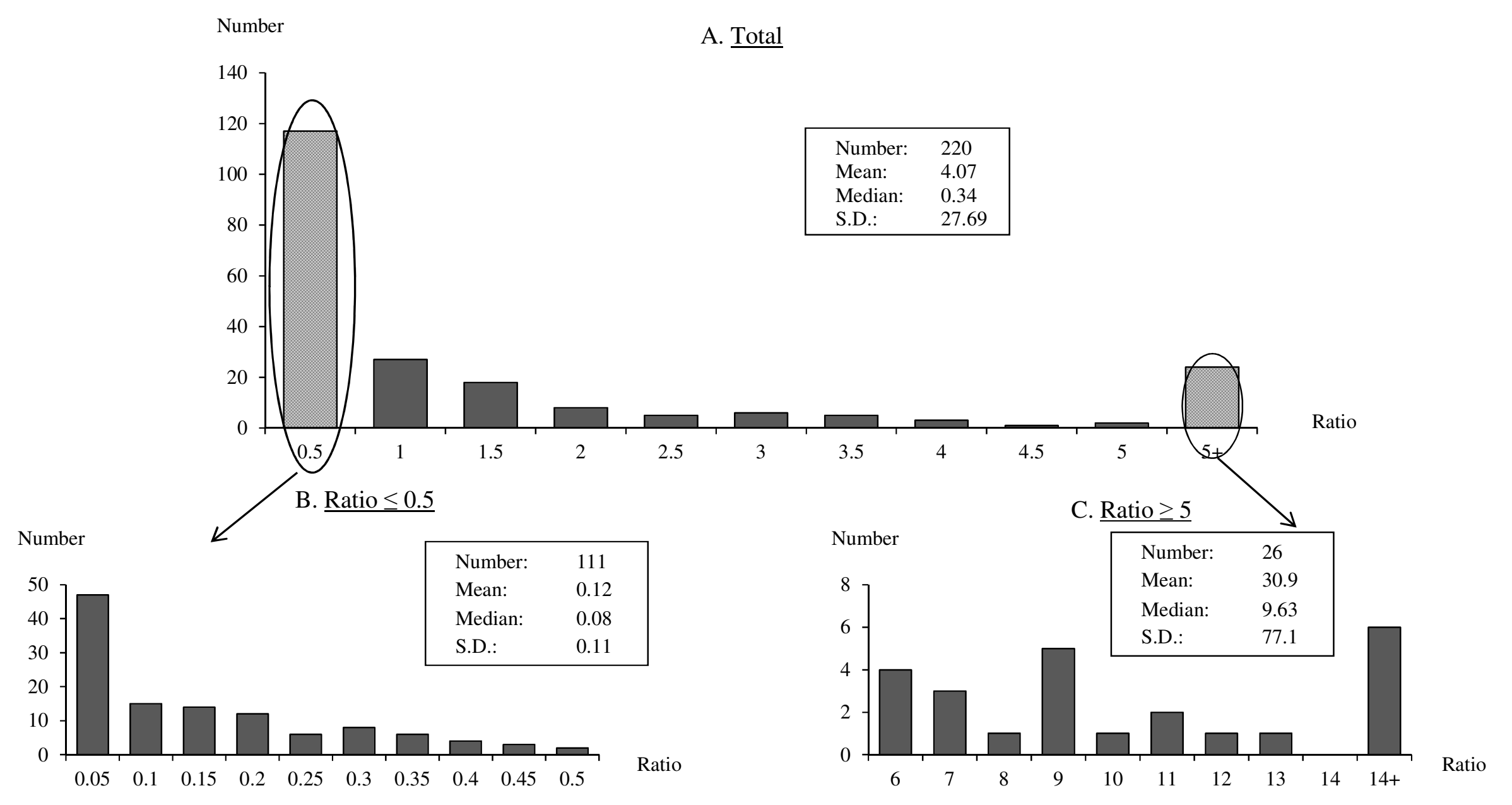

Note: This figure shows the distribution of the ratio of project cost to market capitalisation. For projects with multiple events, we use average project cost and average market capitalisation. 
FIGURE 4

AVERGAE ABNORMAL RETURNS

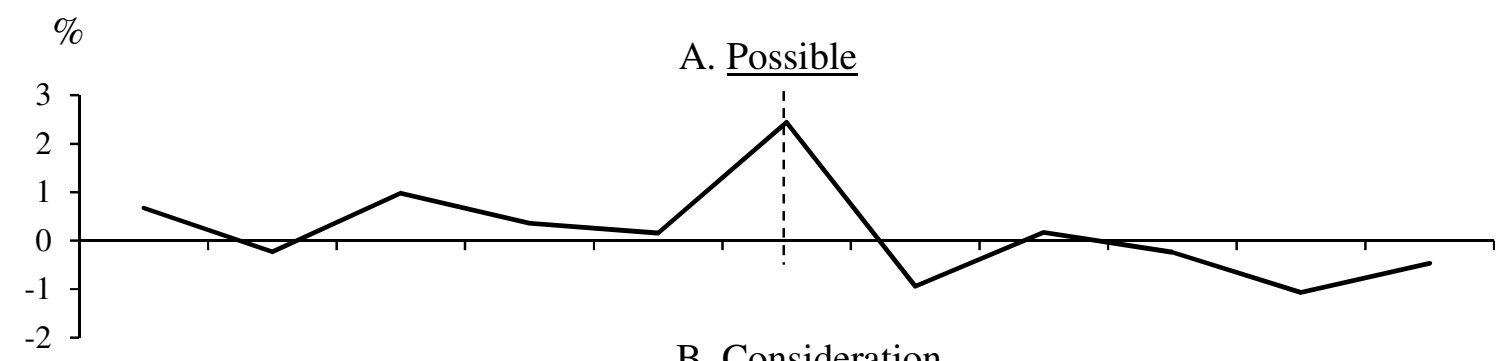

B. Consideration
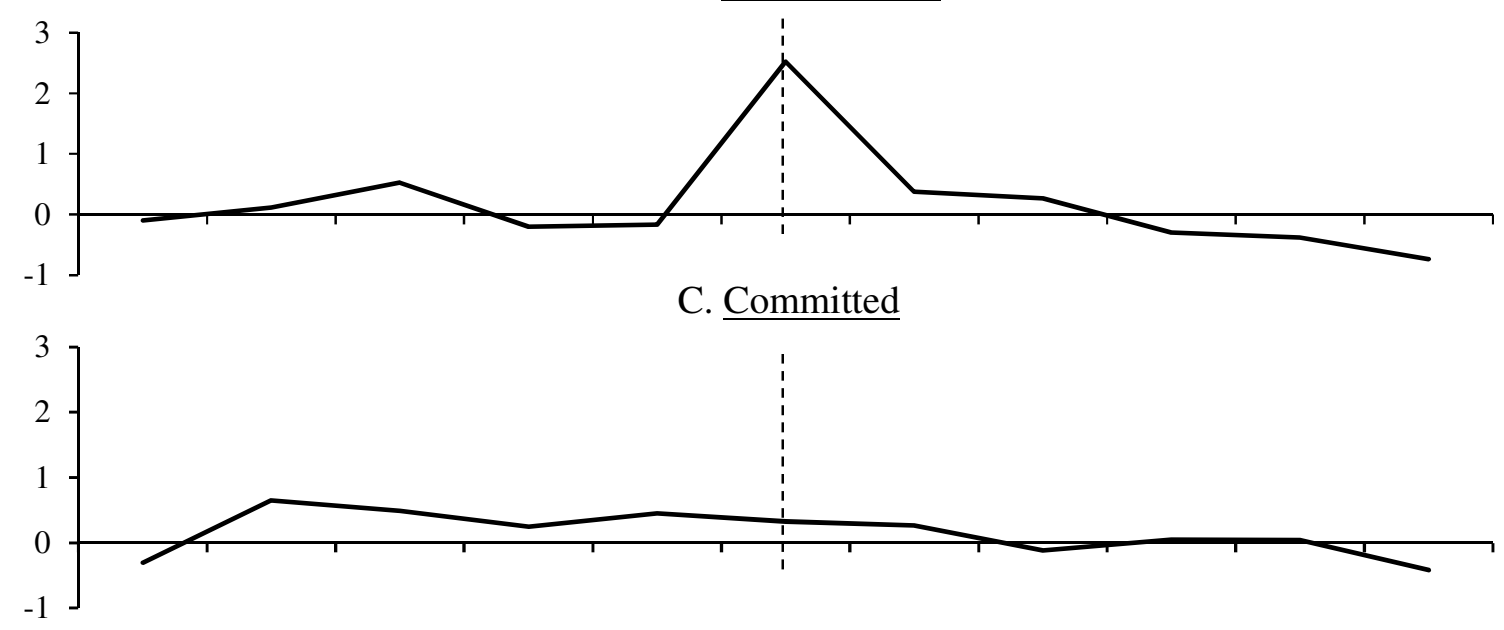

D. Construction
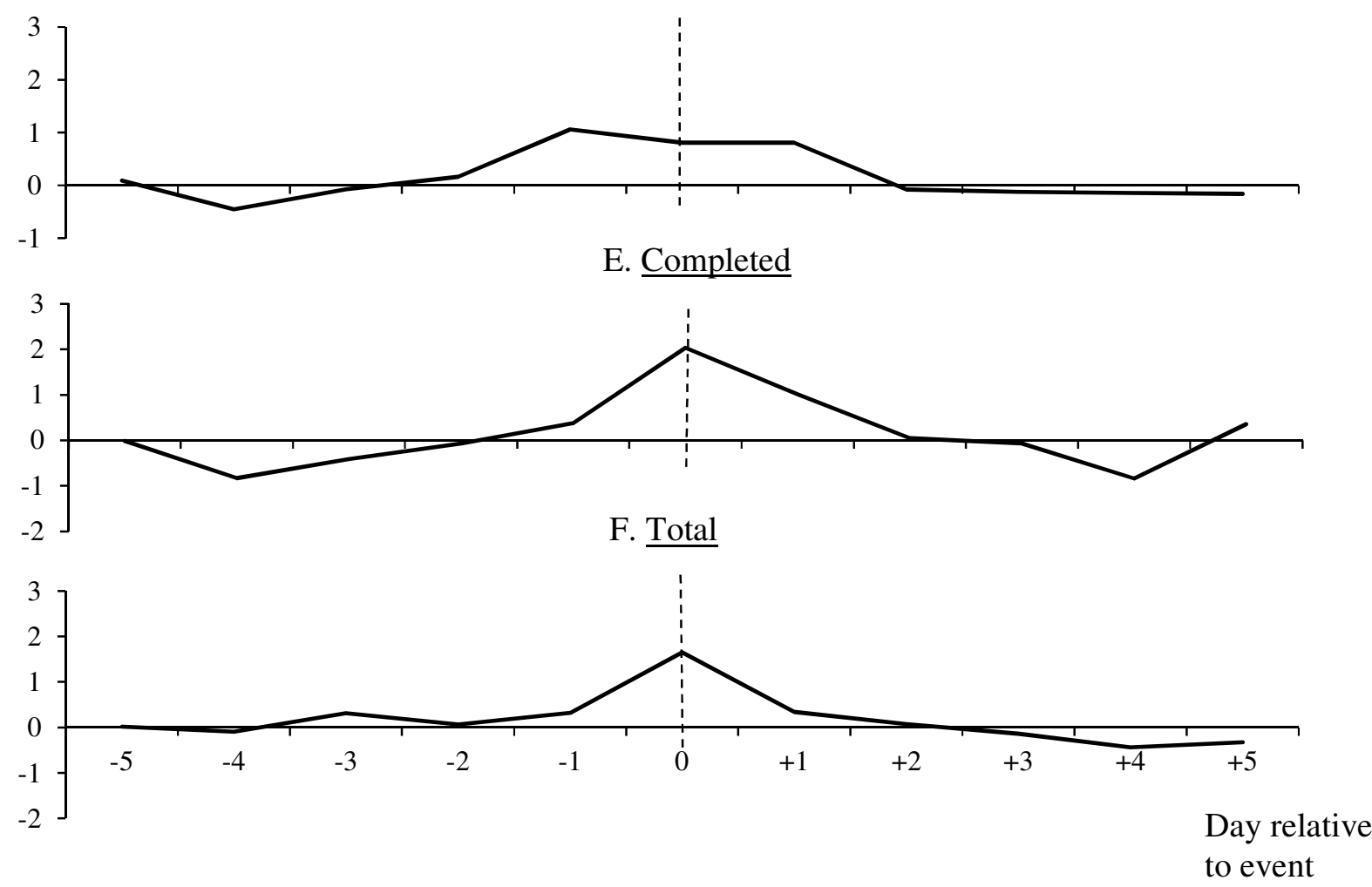
FIGURE 5

AVERAGE CUMULATIVE ABNORMAL RETURNS

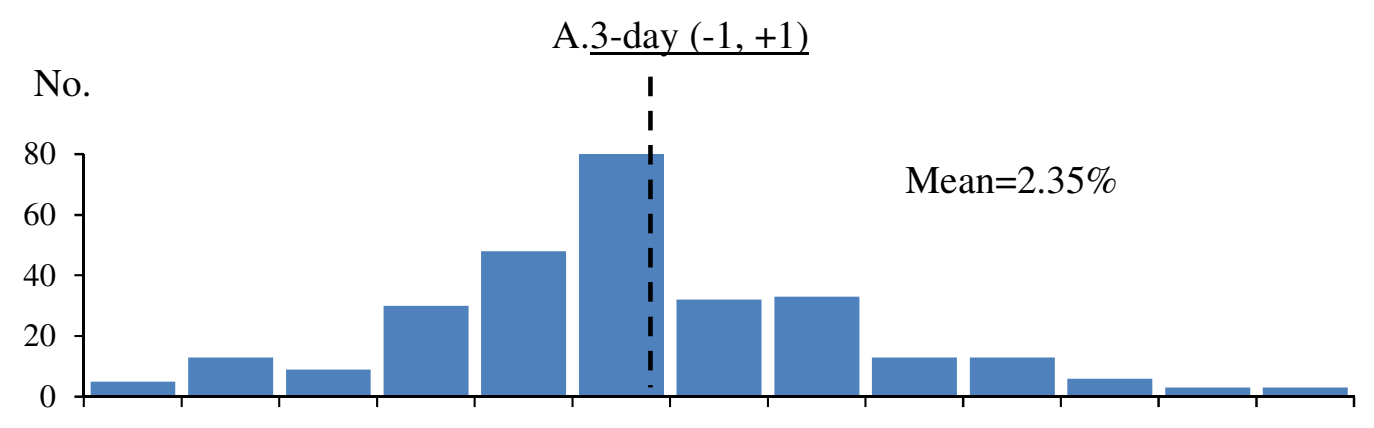

B. Pre-event 10-day $(-10,-1)$

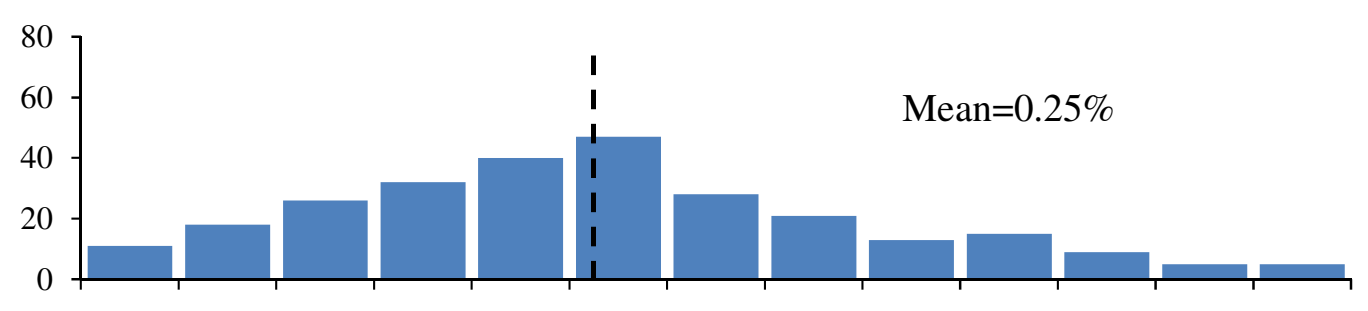

C. Post-event 10-day $(+1,+10)$

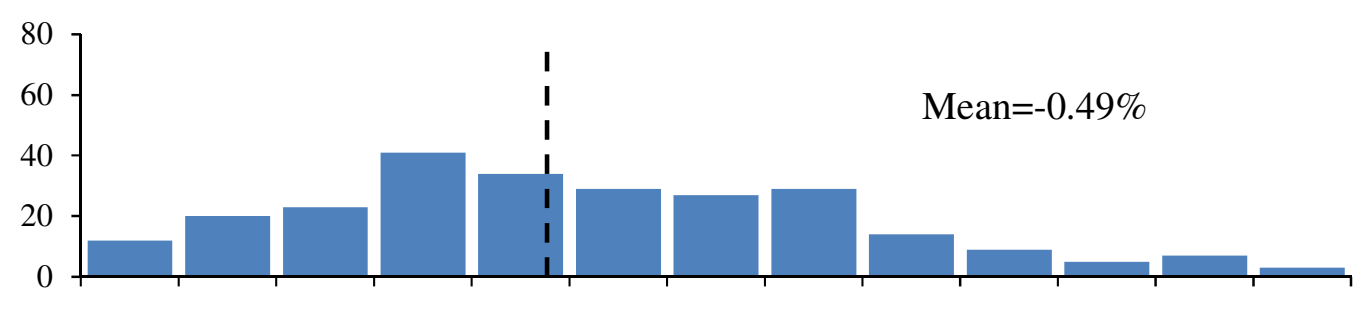

D. 21-day $(-10,+10)$

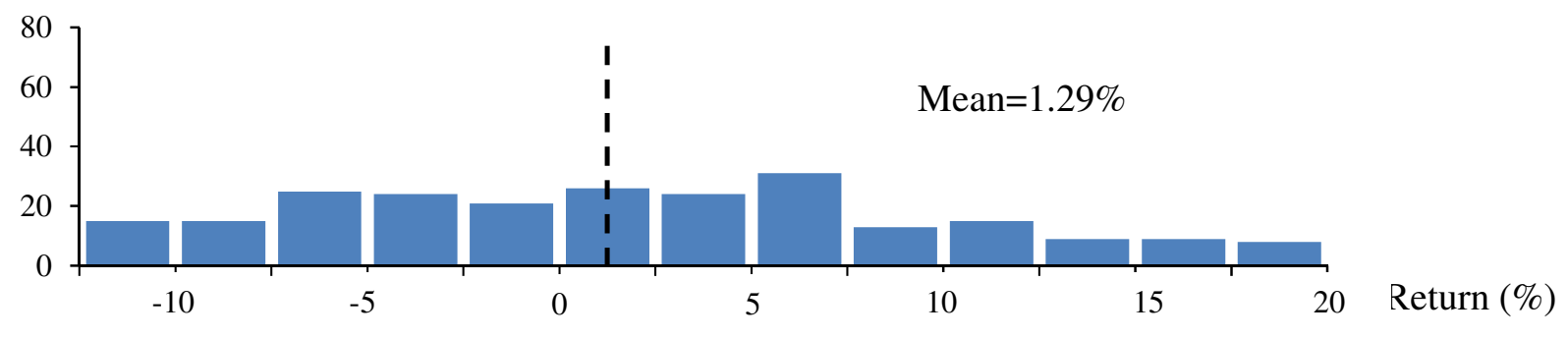


FIGURE 6

VALUE OF RESOURCE PROJECTS

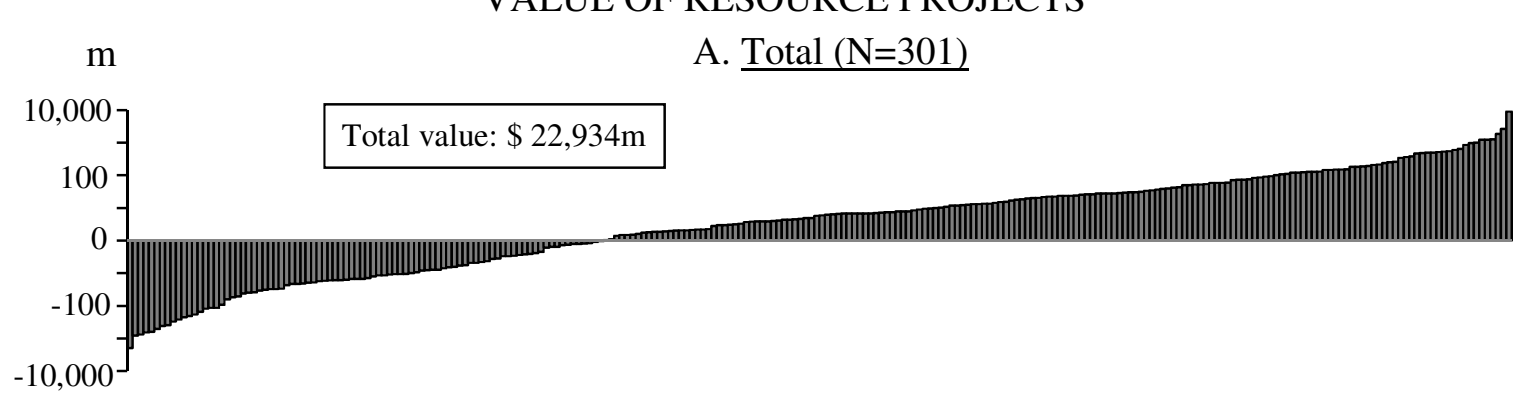

B. Possible $(\mathrm{N}=45)$

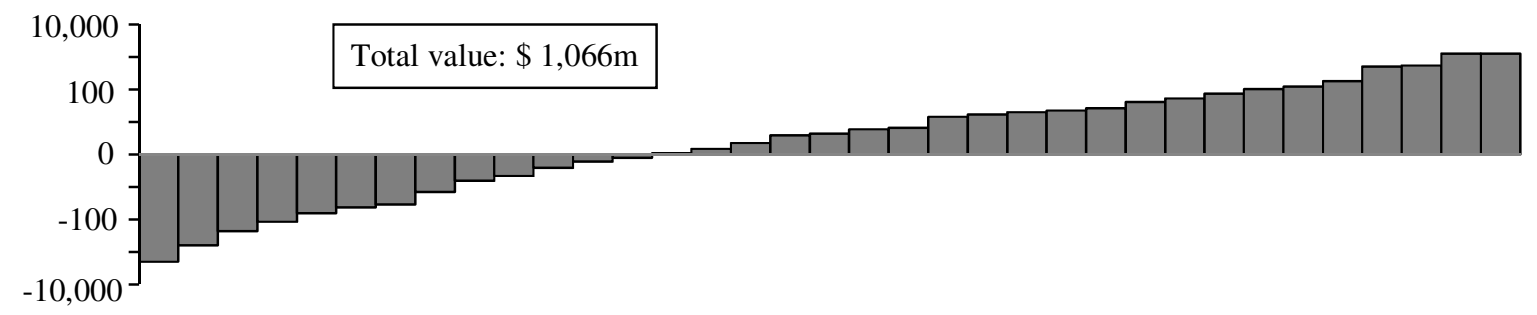

C. Consideration $(\mathrm{N}=84)$

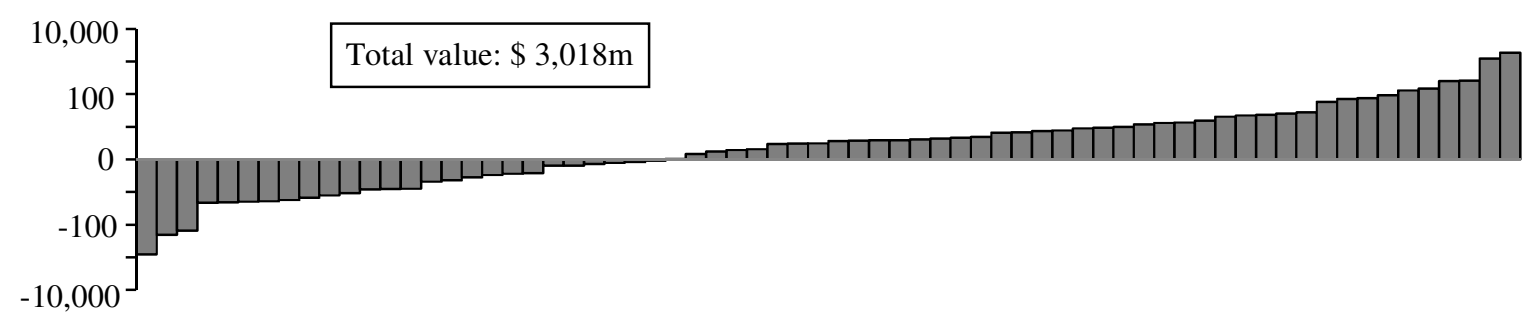

D. Committed ( $\mathrm{N}=66)$

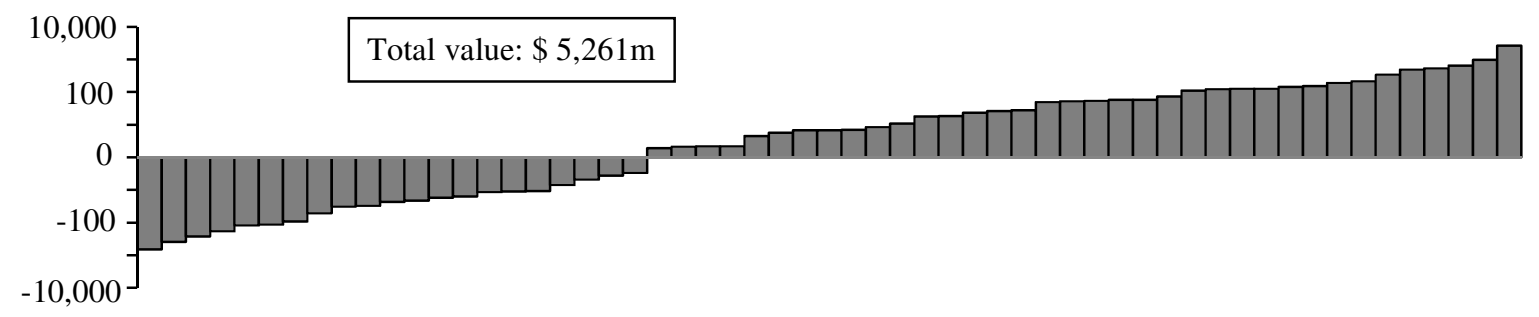

E. Construction $(\mathrm{N}=49)$

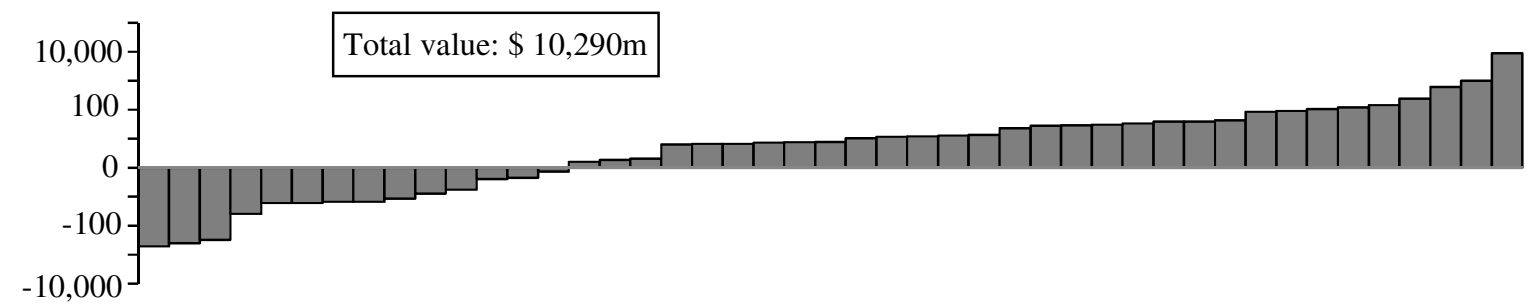

F. Completed $(\mathrm{N}=57)$

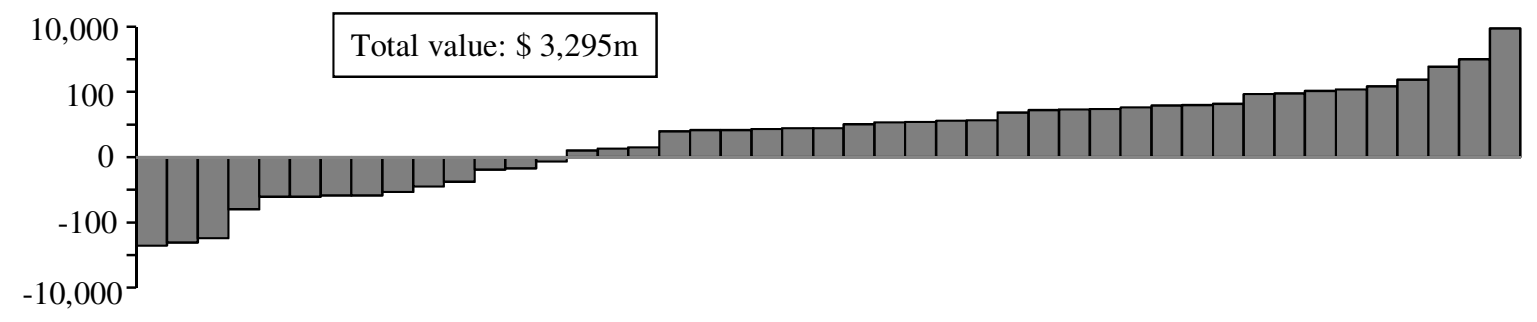

Notes: 1. This figure gives the increased market capitalization of firms around the event announcement, using a 3-day event window.

2. The vertical scale is geometric. 


\section{ECONOMICS DISCUSSION PAPERS}

2010

\begin{tabular}{|c|c|c|}
\hline $\begin{array}{l}\text { DP } \\
\text { NUMBER }\end{array}$ & AUTHORS & TITLE \\
\hline 10.01 & Hendry, D.F. & $\begin{array}{l}\text { RESEARCH AND THE ACADEMIC: A TALE OF } \\
\text { TWO CULTURES }\end{array}$ \\
\hline 10.02 & McLure, M., Turkington, D. and Weber, E.J. & A CONVERSATION WITH ARNOLD ZELLNER \\
\hline 10.03 & $\begin{array}{l}\text { Butler, D.J., Burbank, V.K. and } \\
\text { Chisholm, J.S. }\end{array}$ & $\begin{array}{l}\text { THE FRAMES BEHIND THE GAMES: PLAYER'S } \\
\text { PERCEPTIONS OF PRISONER’S DILEMMA, } \\
\text { CHICKEN, DICTATOR, AND ULTIMATUM } \\
\text { GAMES }\end{array}$ \\
\hline 10.04 & Harris, R.G., Robertson, P.E. and Xu, J.Y. & $\begin{array}{l}\text { THE INTERNATIONAL EFFECTS OF CHINA'S } \\
\text { GROWTH, TRADE AND EDUCATION BOOMS }\end{array}$ \\
\hline 10.05 & Clements, K.W., Mongey, S. and Si, J. & $\begin{array}{l}\text { THE DYNAMICS OF NEW RESOURCE PROJECTS } \\
\text { A PROGRESS REPORT }\end{array}$ \\
\hline 10.06 & Costello, G., Fraser, P. and Groenewold, N. & $\begin{array}{l}\text { HOUSE PRICES, NON-FUNDAMENTAL } \\
\text { COMPONENTS AND INTERSTATE SPILLOVERS: } \\
\text { THE AUSTRALIAN EXPERIENCE }\end{array}$ \\
\hline 10.07 & Clements, K. & $\begin{array}{l}\text { REPORT OF THE } 2009 \text { PHD CONFERENCE IN } \\
\text { ECONOMICS AND BUSINESS }\end{array}$ \\
\hline 10.08 & Robertson, P.E. & $\begin{array}{l}\text { INVESTMENT LED GROWTH IN INDIA: HINDU } \\
\text { FACT OR MYTHOLOGY? }\end{array}$ \\
\hline 10.09 & Fu, D., Wu, Y. and Tang, Y. & $\begin{array}{l}\text { THE EFFECTS OF OWNERSHIP STRUCTURE AND } \\
\text { INDUSTRY CHARACTERISTICS ON EXPORT } \\
\text { PERFORMANCE }\end{array}$ \\
\hline 10.10 & Wu, Y. & $\begin{array}{l}\text { INNOVATION AND ECONOMIC GROWTH IN } \\
\text { CHINA }\end{array}$ \\
\hline 10.11 & Stephens, B.J. & $\begin{array}{l}\text { THE DETERMINANTS OF LABOUR FORCE } \\
\text { STATUS AMONG INDIGENOUS AUSTRALIANS }\end{array}$ \\
\hline 10.12 & Davies, M. & $\begin{array}{l}\text { FINANCING THE BURRA BURRA MINES, SOUTH } \\
\text { AUSTRALIA: LIQUIDITY PROBLEMS AND } \\
\text { RESOLUTIONS }\end{array}$ \\
\hline 10.13 & Tyers, R. and Zhang, Y. & APPRECIATING THE RENMINBI \\
\hline 10.14 & Clements, K.W., Lan, Y. and Seah, S.P. & $\begin{array}{l}\text { THE BIG MAC INDEX TWO DECADES ON } \\
\text { AN EVALUATION OF BURGERNOMICS }\end{array}$ \\
\hline 10.15 & Robertson, P.E. and Xu, J.Y. & $\begin{array}{l}\text { IN CHINA'S WAKE: } \\
\text { HAS ASIA GAINED FROM CHINA'S GROWTH? }\end{array}$ \\
\hline 10.16 & Clements, K.W. and Izan, H.Y. & $\begin{array}{l}\text { THE PAY PARITY MATRIX: A TOOL FOR } \\
\text { ANALYSING THE STRUCTURE OF PAY }\end{array}$ \\
\hline 10.17 & Gao, G. & WORLD FOOD DEMAND \\
\hline 10.18 & $\mathrm{Wu}, \mathrm{Y}$. & $\begin{array}{l}\text { INDIGENOUS INNOVATION IN CHINA: } \\
\text { IMPLICATIONS FOR SUSTAINABLE GROWTH }\end{array}$ \\
\hline 10.19 & Robertson, P.E. & DECIPHERING THE HINDU GROWTH EPIC \\
\hline 10.20 & Stevens, G. & $\begin{array}{l}\text { RESERVE BANK OF AUSTRALIA-THE ROLE OF } \\
\text { FINANCE }\end{array}$ \\
\hline 10.21 & Widmer, P.K., Zweifel, P. and Farsi, M. & $\begin{array}{l}\text { ACCOUNTING FOR HETEROGENEITY IN THE } \\
\text { MEASUREMENT OF HOSPITAL PERFORMANCE }\end{array}$ \\
\hline
\end{tabular}




\begin{tabular}{|l|l|l|}
\hline 10.22 & McLure, M. & $\begin{array}{l}\text { ASSESSMENTS OF A. C. PIGOU'S FELLOWSHIP } \\
\text { THESES }\end{array}$ \\
\hline 10.23 & Poon, A.R. & $\begin{array}{l}\text { THE ECONOMICS OF NONLINEAR PRICING: } \\
\text { EVIDENCE FROM AIRFARES AND GROCERY } \\
\text { PRICES }\end{array}$ \\
\hline 10.24 & Halperin, D. & $\begin{array}{l}\text { FORECASTING METALS RETURNS: A BAYESIAN } \\
\text { DECISION THEORETIC APPROACH }\end{array}$ \\
\hline 10.25 & Clements, K.W. and Si. J. & $\begin{array}{l}\text { THE INVESTMENT PROJECT PIPELINE: COST } \\
\text { ESCALATION, LEAD-TIME, SUCCESS, FAILURE } \\
\text { AND SPEED }\end{array}$ \\
\hline 10.26 & Chen, A., Groenewold, N. and Hagger, A.J. & $\begin{array}{l}\text { THE REGIONAL ECONOMIC EFFECTS OF A } \\
\text { REDUCTION IN CARBON EMISSIONS }\end{array}$ \\
\hline 10.27 & $\begin{array}{l}\text { Siddique, A., Selvanathan, E.A. and } \\
\text { Selvanathan, S. }\end{array}$ & $\begin{array}{l}\text { REMITTANCES AND ECONOMIC GROWTH: } \\
\text { EMPIRICAL EVIDENCE FROM BANGLADESH, } \\
\text { INDIA AND SRI LANKA }\end{array}$ \\
\hline
\end{tabular}




\section{ECONOMICS DISCUSSION PAPERS}

2011

\begin{tabular}{|c|c|c|}
\hline $\begin{array}{l}\text { DP } \\
\text { NUMBER }\end{array}$ & AUTHORS & TITLE \\
\hline 11.01 & Robertson, P.E. & $\begin{array}{l}\text { DEEP IMPACT: CHINA AND THE WORLD } \\
\text { ECONOMY }\end{array}$ \\
\hline 11.02 & Kang, C. and Lee, S.H. & $\begin{array}{l}\text { BEING KNOWLEDGEABLE OR SOCIABLE? } \\
\text { DIFFERENCES IN RELATIVE IMPORTANCE OF } \\
\text { COGNITIVE AND NON-COGNITIVE SKILLS }\end{array}$ \\
\hline 11.03 & Turkington, D. & DIFFERENT CONCEPTS OF MATRIX CALCULUS \\
\hline 11.04 & Golley, J. and Tyers, R. & $\begin{array}{l}\text { CONTRASTING GIANTS: DEMOGRAPHIC CHANGE } \\
\text { AND ECONOMIC PERFORMANCE IN CHINA AND } \\
\text { INDIA }\end{array}$ \\
\hline 11.05 & Collins, J., Baer, B. and Weber, E.J. & $\begin{array}{l}\text { ECONOMIC GROWTH AND EVOLUTION: } \\
\text { PARENTAL PREFERENCE FOR QUALITY AND } \\
\text { QUANTITY OF OFFSPRING }\end{array}$ \\
\hline 11.06 & Turkington, D. & $\begin{array}{l}\text { ON THE DIFFERENTIATION OF THE LOG } \\
\text { LIKELIHOOD FUNCTION USING MATRIX } \\
\text { CALCULUS }\end{array}$ \\
\hline 11.07 & Groenewold, N. and Paterson, J.E.H. & $\begin{array}{l}\text { STOCK PRICES AND EXCHANGE RATES IN } \\
\text { AUSTRALIA: ARE COMMODITY PRICES THE } \\
\text { MISSING LINK? }\end{array}$ \\
\hline 11.08 & Chen, A. and Groenewold, N. & $\begin{array}{l}\text { REDUCING REGIONAL DISPARITIES IN CHINA: IS } \\
\text { INVESTMENT ALLOCATION POLICY EFFECTIVE? }\end{array}$ \\
\hline 11.09 & Williams, A., Birch, E. and Hancock, P. & $\begin{array}{l}\text { THE IMPACT OF ON-LINE LECTURE RECORDINGS } \\
\text { ON STUDENT PERFORMANCE }\end{array}$ \\
\hline 11.10 & Pawley, J. and Weber, E.J. & $\begin{array}{l}\text { INVESTMENT AND TECHNICAL PROGRESS IN THE } \\
\text { G7 COUNTRIES AND AUSTRALIA }\end{array}$ \\
\hline 11.11 & Tyers, R. & $\begin{array}{l}\text { AN ELEMENTAL MACROECONOMIC MODEL FOR } \\
\text { APPLIED ANALYSIS AT UNDERGRADUATE LEVEL }\end{array}$ \\
\hline 11.12 & Clements, K.W. and Gao, G. & QUALITY, QUANTITY, SPENDING AND PRICES \\
\hline 11.13 & Tyers, R. and Zhang, Y. & $\begin{array}{l}\text { JAPAN'S ECONOMIC RECOVERY: INSIGHTS FROM } \\
\text { MULTI-REGION DYNAMICS }\end{array}$ \\
\hline 11.14 & McLure, M. & A. C. PIGOU'S REJECTION OF PARETO'S LAW \\
\hline 11.15 & Kristoffersen, I. & $\begin{array}{l}\text { THE SUBJECTIVE WELLBEING SCALE: HOW } \\
\text { REASONABLE IS THE CARDINALITY } \\
\text { ASSUMPTION? }\end{array}$ \\
\hline 11.16 & Clements, K.W., Izan, H.Y. and Lan, Y. & VOLATILITY AND STOCK PRICE INDEXES \\
\hline 11.17 & Parkinson, M. & $\begin{array}{l}\text { SHANN MEMORIAL LECTURE 2011: SUSTAINABLE } \\
\text { WELLBEING - AN ECONOMIC FUTURE FOR } \\
\text { AUSTRALIA }\end{array}$ \\
\hline 11.18 & Chen, A. and Groenewold, N. & $\begin{array}{l}\text { THE NATIONAL AND REGIONAL EFFECTS OF } \\
\text { FISCAL DECENTRALISATION IN CHINA }\end{array}$ \\
\hline 11.19 & Tyers, R. and Corbett, J. & $\begin{array}{l}\text { JAPAN'S ECONOMIC SLOWDOWN AND ITS } \\
\text { GLOBAL IMPLICATIONS: A REVIEW OF THE } \\
\text { ECONOMIC MODELLING }\end{array}$ \\
\hline 11.20 & Wu, Y. & $\begin{array}{l}\text { GAS MARKET INTEGRATION: GLOBAL TRENDS } \\
\text { AND IMPLICATIONS FOR THE EAS REGION }\end{array}$ \\
\hline 11.21 & Fu, D., Wu, Y. and Tang, Y. & $\begin{array}{l}\text { DOES INNOVATION MATTER FOR CHINESE HIGH- } \\
\text { TECH EXPORTS? A FIRM-LEVEL ANALYSIS }\end{array}$ \\
\hline
\end{tabular}




\begin{tabular}{|l|l|l|}
\hline 11.22 & Fu, D. and Wu, Y. & $\begin{array}{l}\text { EXPORT WAGE PREMIUM IN CHINA'S } \\
\text { MANUFACTURING SECTOR: A FIRM LEVEL } \\
\text { ANALYSIS }\end{array}$ \\
\hline 11.23 & Li, B. and Zhang, J. & $\begin{array}{l}\text { SUBSIDIES IN AN ECONOMY WITH ENDOGENOUS } \\
\text { CYCLES OVER NEOCLASSICAL INVESTMENT AND } \\
\text { NEO-SCHUMPETERIAN INNOVATION REGIMES }\end{array}$ \\
\hline 11.24 & Krey, B., Widmer, P.K. and Zweifel, P. & $\begin{array}{l}\text { EFFICIENT PROVISION OF ELECTRICITY FOR THE } \\
\text { UNITED STATES AND SWITZERLAND }\end{array}$ \\
\hline 11.25 & Wu, Y. & $\begin{array}{l}\text { ENERGY INTENSITY AND ITS DETERMINANTS IN } \\
\text { CHINA'S REGIONAL ECONOMIES }\end{array}$ \\
\hline & & \\
\hline
\end{tabular}




\begin{tabular}{|c|c|c|}
\hline \multicolumn{3}{|c|}{$\begin{array}{c}\text { ECONOMICS DISCUSSION PAPERS } \\
2012\end{array}$} \\
\hline $\begin{array}{l}\text { DP } \\
\text { NUMBER }\end{array}$ & AUTHORS & TITLE \\
\hline 12.01 & Clements, K.W., Gao, G., and Simpson, T. & $\begin{array}{l}\text { DISPARITIES IN INCOMES AND PRICES } \\
\text { INTERNATIONALLY }\end{array}$ \\
\hline 12.02 & Tyers, R. & $\begin{array}{l}\text { THE RISE AND ROBUSTNESS OF ECONOMIC } \\
\text { FREEDOM IN CHINA }\end{array}$ \\
\hline 12.03 & Golley, J. and Tyers, R. & $\begin{array}{l}\text { DEMOGRAPHIC DIVIDENDS, DEPENDENCIES } \\
\text { AND ECONOMIC GROWTH IN CHINA AND INDIA }\end{array}$ \\
\hline 12.04 & Tyers, R. & LOOKING INWARD FOR GROWTH \\
\hline 12.05 & Knight, K. and McLure, M. & THE ELUSIVE ARTHUR PIGOU \\
\hline 12.06 & McLure, M. & $\begin{array}{l}\text { ONE HUNDRED YEARS FROM TODAY: A. C. } \\
\text { PIGOU'S WEALTH AND WELFARE }\end{array}$ \\
\hline 12.07 & Khuu, A. and Weber, E.J. & HOW AUSTRALIAN FARMERS DEAL WITH RISK \\
\hline 12.08 & Chen, M. and Clements, K.W. & PATTERNS IN WORLD METALS PRICES \\
\hline 12.09 & Clements, K.W. & UWA ECONOMICS HONOURS \\
\hline 12.10 & Golley, J. and Tyers, R. & $\begin{array}{l}\text { CHINA'S GENDER IMBALANCE AND ITS } \\
\text { ECONOMIC PERFORMANCE }\end{array}$ \\
\hline 12.11 & Weber, E.J. & $\begin{array}{l}\text { AUSTRALIAN FISCAL POLICY IN THE } \\
\text { AFTERMATH OF THE GLOBAL FINANCIAL } \\
\text { CRISIS }\end{array}$ \\
\hline 12.12 & Hartley, P.R. and Medlock III, K.B. & $\begin{array}{l}\text { CHANGES IN THE OPERATIONAL EFFICIENCY } \\
\text { OF NATIONAL OIL COMPANIES }\end{array}$ \\
\hline 12.13 & $\mathrm{Li}, \mathrm{L}$. & $\begin{array}{l}\text { HOW MUCH ARE RESOURCE PROJECTS WORTH? } \\
\text { A CAPITAL MARKET PERSPECTIVE }\end{array}$ \\
\hline 12.14 & Chen, A. and Groenewold, N. & $\begin{array}{l}\text { THE REGIONAL ECONOMIC EFFECTS OF A } \\
\text { REDUCTION IN CARBON EMISSIONS AND AN } \\
\text { EVALUATION OF OFFSETTING POLICIES IN } \\
\text { CHINA }\end{array}$ \\
\hline 12.15 & Collins, J., Baer, B. and Weber, E.J. & $\begin{array}{l}\text { SEXUAL SELECTION, CONSPICUOUS } \\
\text { CONSUMPTION AND ECONOMIC GROWTH }\end{array}$ \\
\hline
\end{tabular}

